OPEN ACCESS

Edited by:

Mostafa Waly,

Sultan Qaboos University, Oman

Reviewed by: Ala-Eddin Al Moustafa, Qatar University, Qatar Maryam Salami, University of Tehran, Iran

*Correspondence: Helena Jenzer helena.jenzer@puk.zh.ch

Specialty section: This article was submitted to Clinical Nutrition

a section of the journal

Frontiers in Nutrition

Received: 01 August 2019 Accepted: 11 March 2020 Published: 09 April 2020

Citation: Jenzer $H$ and Sadeghi-Reeves $L$ (2020) Nutrigenomics-Associated Impacts of Nutrients on Genes and

Enzymes With Special Consideration

of Aromatase. Front. Nutr. 7:37.

doi: 10.3389/fnut.2020.00037

\section{Nutrigenomics-Associated Impacts of Nutrients on Genes and Enzymes With Special Consideration of Aromatase}

\author{
Helena Jenzer ${ }^{1,2 \star}$ and Leila Sadeghi-Reeves ${ }^{1}$ \\ ${ }^{1}$ Department of Health Professions, aR\&D in Nutrition and Dietetics, Bern University of Applied Sciences BFH, Bern, \\ Switzerland, ${ }^{2}$ Internistic Service, Hospital Pharmacy, Hospital of Psychiatry, University of Zurich, Zurich, Switzerland
}

Interactions are occurring in the course of liberation, absorption, distribution, metabolism, and excretion of active ingredients, or at the target receptors. They are causing therapy failures and undesirable events. Forty-seven of fifty-seven human hepatic isoenzymes are specific and relevant in hormone and vitamin metabolism and biosynthesis. Aromatase (syn. CYP19A1) is one of the specific CYP450 isoenzymes so far not elucidated in detail. As aromatase-inhibiting phytochemicals are currently recommended for breast cancer prevention and as add-on accompanying aromatase-inhibitor pharmacotherapy, it was the aim of this literature review to assess whether a common interpretation on genetic and -omics basis could be found. Articles retrieved showed that traditional antioxidation diet is one of the most approved explanations of inhibition of aromatase by phytonutrients of flavonoid derivatives. Flavonoids compete for the oxygen provided by the heme moiety of aromatase in the course of aromatase-catalyzed conversion of steroid precursors to estrogens. Flavonoids are therefore promoted for breast cancer prevention. A further explanation of flavonoids' mechanism of action proposed was related to enzymatic histone deacetylation. By keeping DNA-structure wide through a high acetylation degree, acetylated histones favor transcription and replication. This mechanism corresponds to a procedure of switching genes on. Inhibiting acetylation and therefore switching genes off might be an important regulation of repressing cancer genes. Aromatase expression depends on the genotype and phenotype of a person. Aromatase itself depends on the expression of the heme moiety encoded in the genotype. Biosynthesis of porphyrins in turn depends on the substrates succinate and glycine, as well as on a series of further enzymes, with ALA synthetase as the rate-limiting step. The effect of the heme moiety as prosthetic group of aromatase further depends on the absorption of iron as a function of $\mathrm{pH}$ and redox state. To assess the function of aromatase precisely, multiple underlying biochemical pathways need to be evaluated. As a conclusion, the genetic regulation of metabolism is a complex procedure affecting multiple pathways. To understand a metabolic step, multiple underlying individually performing reactions need to be considered if personalized (nutritional) medicine should bring an advantage for a patient. Nutrition sciences need to consider the genome of an individual to truly find answers to nutrition-derived non-communicable diseases. 
With current GWAS (genome-wide association study) approaches, inherited errors of metabolism are identified and ideally treated effectively. It is much more difficult to get a precise genetic profile for non-communicable diseases stemming from multifactorial causes. Polygenic risks evaluation is feasible but diagnostic tools are not yet available in a desired extent. Neither flavonoid researchers nor providers of genetic testing kits are going into the details needed for a truly personalized nutritional medicine. The next step with profiling the exome and then the whole genome is on the threshold of becoming routine diagnosis and of bringing the desired details.

Keywords: nutrients, nutrigenomics, aromatase, CYP19A1 isoenzyme, food-drug interactions, healthy aging, personalized nutritional medicine, flavonoids

\section{INTRODUCTION}

Healthy aging, individual lifestyle, and personalized medicine are an attempt to square the circle. Instead of a progredient decline of an aging person's health, disability-free survival is expected to persist until the person's sudden death. It is not well-understood how disability-free survival can be achieved, whether to just live and accept one's fate or to order a genetic testing and apply suitable preventative measures.

There are many examples of senior athletes still able to perform at highest levels, sometimes to break rules such as "they will never come back." Playing tennis in the top 10 even at an age of almost 40 years, playing in ice-hockey top leagues until aged more than 40 years, have been proven to be feasible. Obviously, adaption is one of the keys to remain competitive (1). It is however more difficult for ordinary people to maintain health and performance at later phases of life.

To prevent a progredient decrease in the quality of life, various recommendations are brought to the market often for commercial purposes and seldom for truly providing more quality of life nor evident added value $(2,3)$. Nutritional behavior might contribute to deteriorate chronic non-communicable diseases. Yet, simple associations with disease incidences are hardly ever convincingly evident. Overrepresented old publications are often taken as standard although biases and confounding factors (4).

Healthy aging might depend on a well-tuned adaption of an eating behavior to an individual's metabolism. Apart from diet, physical activity is promoted to maintain a person's and the population's health. However, one-fits-all strategies such as the "eat the rainbow" mantra or the Swiss Food Pyramid do not consider personalized nutritional medicine (5). Recommended daily allowances, e.g., DACH recommendations (6), are based on epidemiological data arising from the need of defined small healthy population groups. These general needs are corrected by two standard deviations and additional amounts to compensate losses from bad accessibility to nutrients from foodstuff or from processing. In addition, special physiological conditions such as pregnancy justify an extra supplement. Recommended daily allowances are therefore unprecise from a nutritional medicine point of view as they do not consider adequately individual needs.

Nutrition research is under pressure due to poor methodologies. Solutions will not come from more and more papers based on qualitative research or from small randomized trials (7). Even the Predimed study which has shown a risk reduction by intake of olive oil and nuts cannot be transferred simply from the Spanish study population to other ethnicities with different nutritional behaviors (8). Therefore, methods have to be expanded or changed. Suitable approaches such as the use of OMICS technologies show promising results in finding reasons why individuals response differently to the same foodstuff or consumption of plant food ${ }^{1}$.

Consuming a number of diets without reflection is not a suitable strategy for healthy aging. Once food and medicines are consumed, interactions are occurring in the course of liberation, absorption, distribution, metabolism, and excretion of active ingredients, or at the target receptors. They are causing therapy failures and undesirable events. As only some 10 of 57 human hepatic non-specific CYP450 isoenzymes are considered important in drug-drug interactions, the expansion of research to specific CYP450 isoenzymes relevant for food-drug interactions, such as aromatase (syn. CYP19A1, EC 1.14.14.1), is a neglected issue in nutrition research. As phytochemicals are currently recommended for breast cancer prevention and as addon accompanying aromatase-inhibitor pharmacotherapy, a fresh look at the favorite mechanisms is needed.

The aim of this review is:

- To shed light on the link between non-communicable diseases and underlying nutritional behaviors as well as on the inheritability of metabolic performance and their impact on these diseases

- To assess whether explanations beyond pure chemical mechanisms of action are described in the literature and whether a common interpretation based on genetic and omics technologies is found.

\section{METHODOLOGY}

A semi-systematic online literature search was performed on the platforms Medline ${ }^{\circledR}$, Sciencedirect ${ }^{\circledR}$, Embase ${ }^{\circledR}$, and Scholar Google ${ }^{\circledR}$ using mesh terms and keywords for several topics of interest. The review strategies including the search and selection of the articles are based on PRISMA guidelines for Systematic

\footnotetext{
${ }^{1}$ COST Action FA1403 (POSITIVe, https://www6.inra.fr/cost-positive).
} 
Reviews and Meta-Analyses (9). The studies were related to the influence of nutrients on cytochrome P450 and how diet can affect metabolic biochemical pathways. Information was interpreted immediately. New keywords were defined for a stepby-step incremental progress and reentered into the search engines for a second and third run on each of the search chapters.

Firstly, basic search was performed on pharmacokinetics and nutrients, substrates, inhibitors, inducers of human CYP450 isoenzymes, CYP19A1, aromatase, gender, pharmacodynamics and targets of bioactive, food-drug interactions, nutrigenomics, aromatase, and flavonoids. A literature research yielded 2954 bibliographic records in the first run with "[(breast cancer) AND (cytochrome P450)]" keywords and 5307 with "(cytochrome P450) AND nutrients." Duplicates were identified and removed from the pool of bibliographic records. Next, an accurate screening of abstracts and titles was performed to determine the most relevant articles. Afterwards, full articles were reviewed using the following inclusion criteria: (1) studies which provided information about the relationship between nutrition and breast cancer; (2) studies which explained the metabolic pathways of cytochrome P450 enzymes; (3) studies which explained how some nutrients interact with substrates metabolized by cytochrome P450 enzymes; (4) studies which provided clinical information about the pathogenesis of breast cancer; (5) studies which provided information about any cytochrome P450 enzyme. In conclusion, 52 studies were first retained, mostly recent studies but also some earlier studies presenting analyses that were not found in the most recent studies.

Secondly, the mechanistic pattern was semi-systematically expanded to mechanistical explorations on specific enzymology information about aromatase, breast cancer, breast cancer associated to nutrition, cytochrome $\mathrm{P} 450$ associated to breast cancer, nutrition and cancer, natural aromatase inhibitors, risk factors for breast cancer, complementary therapies, and breast cancer.

Thirdly, non-systematic specific search terms on nutrigenomics and biochemical ascending and descending pathways in the aromatase metabolism were searched.

Integration was approached in deductive reflection rounds. Substantial bricks were assembled to a comprehensive nutritionrelevant pattern of personalized nutritional medicine.

\section{RESULTS AND INTERPRETATION}

\section{Pharmaco- and Nutrient-Kinetic Considerations: Principles, Commonalities, and Diversity of Gender- and Age-Related Metabolic Capacity \\ From Bioactive to Effect-The LADME Processes}

Medicines or foods will be either readily incorporated if comparable to physiological substrates or metabolized for elimination as xenobiotics. The processes of the passage of xenobiotics across the intestinal wall, the body compartments and organs until receptors are found, are qualitatively described in the chronological kinetic steps Liberation, Absorption, Distribution, Metabolism, and Excretion and in the dynamic steps at the target/receptor as depicted in the Ariens Scheme $[(10,11)$; Figure 1].

To cope with variability in these processes genetic approaches have to be applied. Mutations on a single nucleotide (SNM, single nucleotide mutation) results in a genotype diversity and therefore different metabolic capacities, seen as polymorphisms in a population. Polymorphisms are a frequent reason for adverse drug events which increase in the case of polypharmacy. The interaction risk for a combination of 2 drugs is $13 \%$, for 4 drugs $38 \%$, and for 7 drugs $82 \%$ (12). In-patients receive 5-7 drugs. Thus, pharmacokinetic considerations are crucial. No estimation for food-food and food-drug interactions is available although they seem to occur even more frequent than drug-drug interactions. One of the reasons might be the lower severity of incidences. The higher probability of foodnutrient-drug interaction can be presumed by the vast amounts of food ingredients and the higher number of hepatic isoenzymes involved in this complex metabolism than in drug metabolism.

Ethnical groups show typical phenotypes. For instance, due to a mutation on the gene coding for the CYP2D6 isoenzyme in the Asian population, drugs being metabolized by this isoenzyme contain only $50 \%$ of the dose used in Europe. This mutation is important since many drugs (and possibly secondary nutrients) are metabolized by CYP2D6. For nutritional substrates less data and no interaction tables are available (13).

The objective of nutrigenomics research is to understand how nutrients influence gene and protein expression and why this expression varies between individuals. It is wellknown that even though individuals were to eat similarly, some will become obese, others will develop cardiovascular diseases, or allergies. A recent project aiming at promoting research on interindividual differences has been adopted by the governments of COST member countries (COST action FA1401: "Interindividual variation in response to consumption of plant food bioactives and determinants involved (POSITIVe), https:// www.cost.eu/actions/FA1403/\#tabs|Name:overview)"1.

Evolution, globalization, and internationalization of nutritional habits make genetic impacts slowly disappear by genetic recombination and/or by adaption. Epidemiologic assessments are more and more difficult to interpret since at least in Western countries mixed populations lead to a recombination of genetic codes. Otherwise, as foodstuff consumed is not only produced in the consumers region as compared to times of regionally dominated markets, but is rather of international provenance containing new ingredients and components, genes do not only determine how food is metabolized, but food acts the other way around, i.e., by putting pressure on long-term genetic and medium-term epigenetic adaption. This will lead to new diagnostic tools such as genetic profiling and to novel interventions on an individual level (14-23).

\section{Bioaccessibility and Liberation of Bioactives}

Flavonoid-remnants of processed flavonoid-rich foods show various degradation patterns and quantities depending on the excess steam and heat applied. Tomato ingredients seem to be steam-volatile as Italian sugo for instance keeps more lutein, $\beta$ carotene, and lycopene than steamed tomatoes. Long heating 

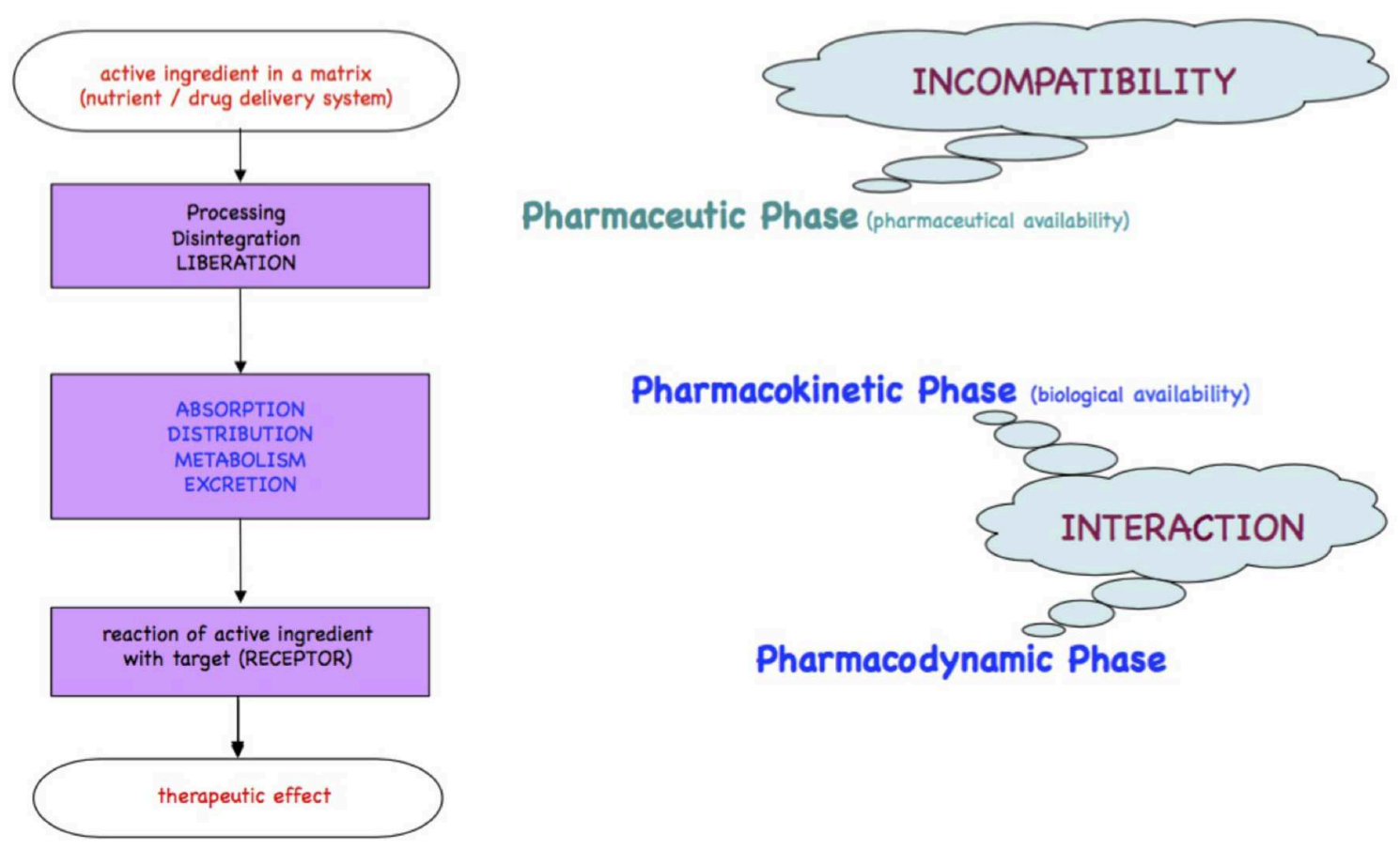

FIGURE 1 | Ariens Scheme. A substrate freely accessible from a medicinal product or from foodstuff is orally taken and passes the pharmacokinetic LADME steps (liberation, absorption, distribution, metabolism, excretion). A part of the bioactive or xenobiotic may find in the pharmacodynamic step its targets such as receptors at cell surfaces, cell nuclei, or circulating metabolites to yield an effect.

processes lead to degradation of anthocyanidins in blueberries as only $3 \%$ remain after blueberry jam production. Precious Mungo sprouts components (genistein, daidzein) are fairly wellconserved by gentle roasting. Green tea macerated in $80^{\circ} \mathrm{C}$ water for 3 min keeps higher bioactive contents than when extracted at hotter temperatures (24).

\section{Absorption and Distribution}

Absorption of nutrients and xenobiotics is mainly an individualized procedure depending on a human being's metabolic capacity. This in turn varies with age, gender, ethnicity, and inherited metabolic performance. Gastric tube's morphology and physiological function shows major gender differences. In men the mean gastric fasting $\mathrm{pH}$ is 2.15 whereas it is situated between a range of 2.5 and 2.8 in women. This is a nearly 5-fold higher acidity in a male stomach and explains the higher prevalence of duodenal ulcers in men. A sufficiently acidic $\mathrm{pH}$ below 3.5 is determinant for the activation of pepsin from its precursor pepsinogen, duodenal secretin stimulation (at $\mathrm{pH}$ 4.0-4.5), and pancreatic enzymes' release as well. Gastric and intestinal liquid differ in volume (bigger in men), in emptying, in gastrin and bicarbonate concentration, and in colon transit times (shorter in men). Female hormone regulation by estrogens and progesterone is depressing gastrointestinal motility in women especially in pregnancy. Endocrine secretion in women is triggered when nutrients are provided and not permanently as compared to men's endocrine secretion and growth hormone release. Acidity at this upper GI tube is increasing from the fasting $\mathrm{pH}$ of $2-5$ to $\mathrm{pH} 1.7$ immediately after a meal intake and dropping to $\mathrm{pH} 4.3$ toward the end of the digestion procedures after $2-3 \mathrm{~h}$. As a summary, absorption is "quantitatively and qualitatively influenced by gastrointestinal $\mathrm{pH}$ and by intestinal motility" (12). On the other hand, absorption of precious nutrients is substantially decreased by tannins from tea or coffee due to precipitations (25).

For pepsin activation, which depends on a $\mathrm{pH}<3.0-3.5$, and bactericidal effect, higher gastric $\mathrm{pH}$ of women would do as well. However, the gastrointestinal milieu changes fundamentally $\mathrm{pH}$ permanently to $>4$ both upon medication with antacids such as proton pump inhibitors (PPIs) and as a result of aging.

Drug or nutrient availability does not depend only on active carrier driven transports, but also on diffusion. Longterm PPI treatment switches the stomach's function almost permanently off. The underlying $\mathrm{pH}$ change has consequences for the solubility and therefore for the bioavailability of a important number of micronutrients such as vitamins C, B12, folate, and oligo-elements such as zinc, iron, magnesium, and calcium, and even of medicines such as ketoconazole, itraconazole, atazanvir, cefpodoxime, cinnarizine, enoxacin, dipyridamole, various oligoelements, or ascorbic acid, which are less bioavailable, and of nifedipine, digoxin, penicillin, erythromycin, or alendronate, which are more bioavailable (26-31).

Transport across the membranes and thus efficacy depend dramatically on gastrointestinal $\mathrm{pH}$ conditions. These transports may be bidirectional. Whether or not non-dissociated or dissociated substrates will be more readily absorbed depends on the absorption mechanism and the similarity to physiological 
molecules (passive diffusion, carrier-mediated transport, etc.). An important membrane-bound transporter at the apical side of enterocytes and at many other membranes, e.g., liver and blood-brain-barrier, is the P-glycoprotein (P-gp). P-gp is multi-drug-resistance1-Gene (MDR1) which builds an efflux of xenobiotics out into the lumen. It is often co-localized with CYP3A4,5,7 isoenzymes., For the P-gp substrates, just as for these isoenzymes, inhibitors and inducers can be distinguished $(12,25) . \mathrm{pH}$ is not only determinant for absorption of nutrients, but also for non-nutrient substrates, e.g., allergens and other xenobiotics such as non-steroidal-anti-inflammatory drugs (NSAIDs) or benzodiazepines. These xenobiotics have rather low $\mathrm{pK}_{\mathrm{a}}$ values. Their absorption by passive diffusion therefore needs acidic $\mathrm{pH}$ conditions for absorption from the upper GI tube and treatments with antacids such as PPIs are likely to inhibit the quantitative absorption of NSAIDs or benzodiazepines and result in clearly lower anti-inflammatory effects (32).

Carbonates as antacids currently used in single doses beyond $1 \mathrm{~g}$, "will have an onset of about $6 \mathrm{~min}$ and a time with $\mathrm{pH}$ values over 3.0 of about $2 \frac{1}{2} \mathrm{~h}$." Ranitidine, meanwhile obsolete as $\mathrm{H}_{2}$ antagonist, was used for reflux in doses of $75 \mathrm{mg}$ which led to an onset of $65 \mathrm{~min}$. Its effect was rather unreliable and lasted for $36 \mathrm{~min}$ to $13 \mathrm{~h} \mathrm{(33).} \mathrm{As} \mathrm{a} \mathrm{comparison,} \mathrm{today's} \mathrm{favorites} \mathrm{and}$ blockbusters pantoprazole and esomeprazole (both used in daily doses of $40 \mathrm{mg}$ ) yield a median $24 \mathrm{~h} \mathrm{pH}$ of $3.7 \mathrm{vs.} 4.7$ in the steady state after 5 days. Long-term treatments with esomeprazol and pantoprazole have antacid effects of keeping gastric $\mathrm{pH}$ over 4 for 16.1 and $10.8 \mathrm{~h}$, respectively. The long half-life times of these PPIs cannot be antagonized by any antidot. $\mathrm{pH}$ must in situations of need be imitated by ingestion of acidic beverages. Restoration ad integrum of the proton pump by de novo biosynthesis of the $\mathrm{H}^{+} \mathrm{K}^{+}$-exchanging ATPase will last several days. "The production half-life is approximately $50 \mathrm{~h}$ " (34-38).

Digestion-resistance during gastrointestinal transit is an important feature of food allergens. This resistance is supported by antacids, e.g., PPIs. A particular risk is arising for elderly patients suffering from gastroenterological diseases, tumors, and infections and consuming regularly "crustacean, eggs, fish, milk, peanuts, soybeans, tree nuts or fruits, and wheat." In addition, with the loss of gastric acidity, the antibacterial intestinal activity becomes ineffective. Therefore, a net risk of "bacterial overgrowth of Clostridium difficile, Campylobacter jejuni, and Salmonella ssp." is emerging. "This is also true for the inflammation, ulcer, and stomach cancer associated Helicobacter pylori which produces big amount of urease leading to a shift in gastric $\mathrm{pH}$ from between 2.2 and 2.8 to a range of $6-7$ " (39-42). There is a strong correlation between PPI treatments and "various pathologies such as lactose intolerance, celiac disease, atrophic gastritis, rheumatoid arthritis, and/or diabetes mellitus" (4346). It is highly important to consider the consequences of $\mathrm{pH}$ increase on absorption of micronutrients, mainly iron, copper, and further co-factors of essential enzymatic metabolic reactions. Whereas, B-vitamins are co-enzymes in pyruvate decarboxylation and citric acid cycle, iron and copper are needed in the oxidative phosphorylation (respiratory chain) as part of some of the five enzyme complexes and as prosthetic group in hemoproteins.

Absorption of such oligo-elements follows the rules of solubility of aqua-complexes which is in turn dramatically depending on $\mathrm{pH}$. The example of iron aqua-complexes shows that at $\mathrm{pH}$ conditions encountered at the jejuno-duodenal junction, where $\mathrm{pH}$ raises steeply, iron becomes less soluble as a result of a sequence of deprotonations of its aquacomplexes from a 3- or 2-fold positively charged to an uncharged insoluble complex in both cases of ferric iron and ferrous iron: (32, 47-49).

$$
\begin{array}{lr}
{\left[\mathrm{Fe}\left(\mathrm{H}_{2} \mathrm{O}\right)_{6}\right]^{3+}>\left[\mathrm{Fe}\left(\mathrm{H}_{2} \mathrm{O}\right)_{5}(\mathrm{OH})\right]^{2+}+\mathrm{H}^{+}} & \left(\mathrm{pK}_{\mathrm{a}} 2.2\right) \\
{\left[\mathrm{Fe}\left(\mathrm{H}_{2} \mathrm{O}\right)_{5}(\mathrm{OH})\right]^{2+}->\left[\mathrm{Fe}\left(\mathrm{H}_{2} \mathrm{O}\right)_{4}(\mathrm{OH})_{2}\right]^{+}+\mathrm{H}^{+}} & \left(\mathrm{pK}_{\mathrm{a}} 3.5\right) \\
\left.\mathrm{Fe}\left(\mathrm{H}_{2} \mathrm{O}\right)_{4}(\mathrm{OH})_{2}\right]^{+}->\left[\mathrm{Fe}\left(\mathrm{H}_{2} \mathrm{O}\right)_{3}(\mathrm{OH})_{3}\right]^{0}+\mathrm{H}^{+} & \left(\mathrm{pK}_{\mathrm{a}} 6.0\right) \\
{\left[\mathrm{Fe}\left(\mathrm{H}_{2} \mathrm{O}\right)_{6}\right]^{2+}>\left[\mathrm{Fe}\left(\mathrm{H}_{2} \mathrm{O}\right)_{5}(\mathrm{OH})\right]^{+}+\mathrm{H}^{+}} & \left(\mathrm{pK}_{\mathrm{a}} 6.74\right) \\
{\left[\mathrm{Fe}\left(\mathrm{H}_{2} \mathrm{O}\right)_{5}(\mathrm{OH})\right]^{+}->\left[\mathrm{Fe}\left(\mathrm{H}_{2} \mathrm{O}\right)_{4}(\mathrm{OH})_{2}\right]^{0}+\mathrm{H}^{+}} & \left(\mathrm{pK}_{\mathrm{a}} 9.5\right)
\end{array}
$$

These mechanisms lead to iron precipitates in the course of the passage along the GI tube starting to be relevant from about $\mathrm{pH}$ 3 upwards (Figures 2A,B). Precipitates are composed of colloidal and amorphous ferric iron hydroxides. Condensation is triggered by deletion of water out of the complexes and formation of hydroxo bridges. It is obvious that that such an amorphous mass cannot be absorbed from the GI tube.

Anemia caused by iron deficiency is treated more successfully by medicines containing ferrous iron $\mathrm{Fe}(\mathrm{II}+)$ as an active ingredient, because the main loss of the alternative ferric iron would result close to the junction of duodenum to jejunum when within $10 \mathrm{~cm}$ distance alkaline conditions become predominant. Remaining ferric iron may be reduced in the distal duodenum to its ferrous form $\left[\mathrm{Fe}\left(\mathrm{H}_{2} \mathrm{O}\right)_{6}\right]^{2+}$. Ferrous condensates form only at alkaline conditions. This is the reason why ferrous iron is absorbed more readily than ferric iron which is at these $\mathrm{pH}$ conditions already precipitated and lost for absorption. It is wise to supply iron dissolved in fruit juice such as orange juice due to ascorbic acid contributing to the stabilization of better absorbable ferrous iron, increasing the absorbed amount up to 3 -fold. The role of ascorbic acid contained in fruit juice is to enhance acidic conditions in the absorption region in case of PPI treatment and to reduced ferric to ferrous iron. The repeated supply of smaller amounts of oligoelements is more likely to lead to an efficient absorption and distribution than with high loading doses. Copper and cobalt but not manganese and zinc aquo-complexes suffer as well from partial loss when $\mathrm{pH}$ conditions are unfavorable for absorption (32, 47-49).

Depending on age, gender, physical activity and many more factors, the ratios of body compartments vary and therefore the distribution according to the hydrophilic-lipophilic profile of a substrate.

\section{Ontogeny, peri- and post-natal phase, adaption, lactation}

Availability of active pharmaceutical ingredients is particularly low in newborns as metabolizing enzymes in the liver are most active after birth and declining when age increases. Not only activity but also inducibility is highest in newborns. However, post-natal inducibility is lower than in the embryo stage. Peaks 


\section{A}

$\left[\mathrm{Fe}\left(\mathrm{H}_{2} \mathrm{O}\right)_{6}\right]^{3+} \rightarrow\left[\mathrm{Fe}\left(\mathrm{H}_{2} \mathrm{O}\right)_{5}(\mathrm{OH})\right]^{2+} \rightarrow\left[\mathrm{Fe}\left(\mathrm{H}_{2} \mathrm{O}\right)_{4}(\mathrm{OH})_{2}\right]^{++}>\left[\mathrm{Fe}\left(\mathrm{H}_{2} \mathrm{O}\right)_{3}(\mathrm{OH})_{3}\right]^{0}$
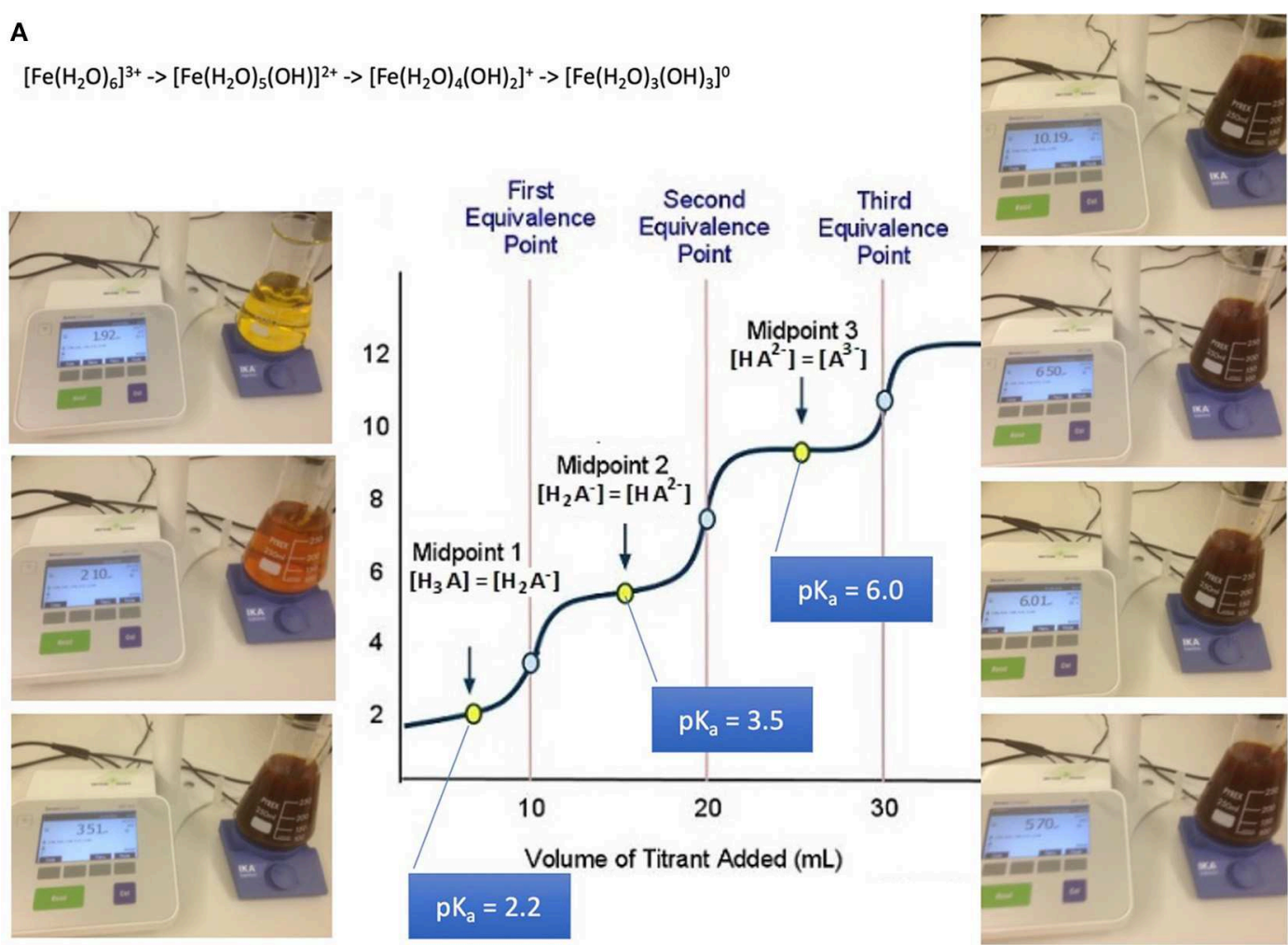

B

$\left[\mathrm{Fe}\left(\mathrm{H}_{2} \mathrm{O}\right)_{6}\right]^{2+} \rightarrow\left[\mathrm{Fe}\left(\mathrm{H}_{2} \mathrm{O}\right)_{5}(\mathrm{OH})\right]^{+} \rightarrow\left[\mathrm{Fe}\left(\mathrm{H}_{2} \mathrm{O}\right)_{4}(\mathrm{OH})_{2}\right]^{0}$

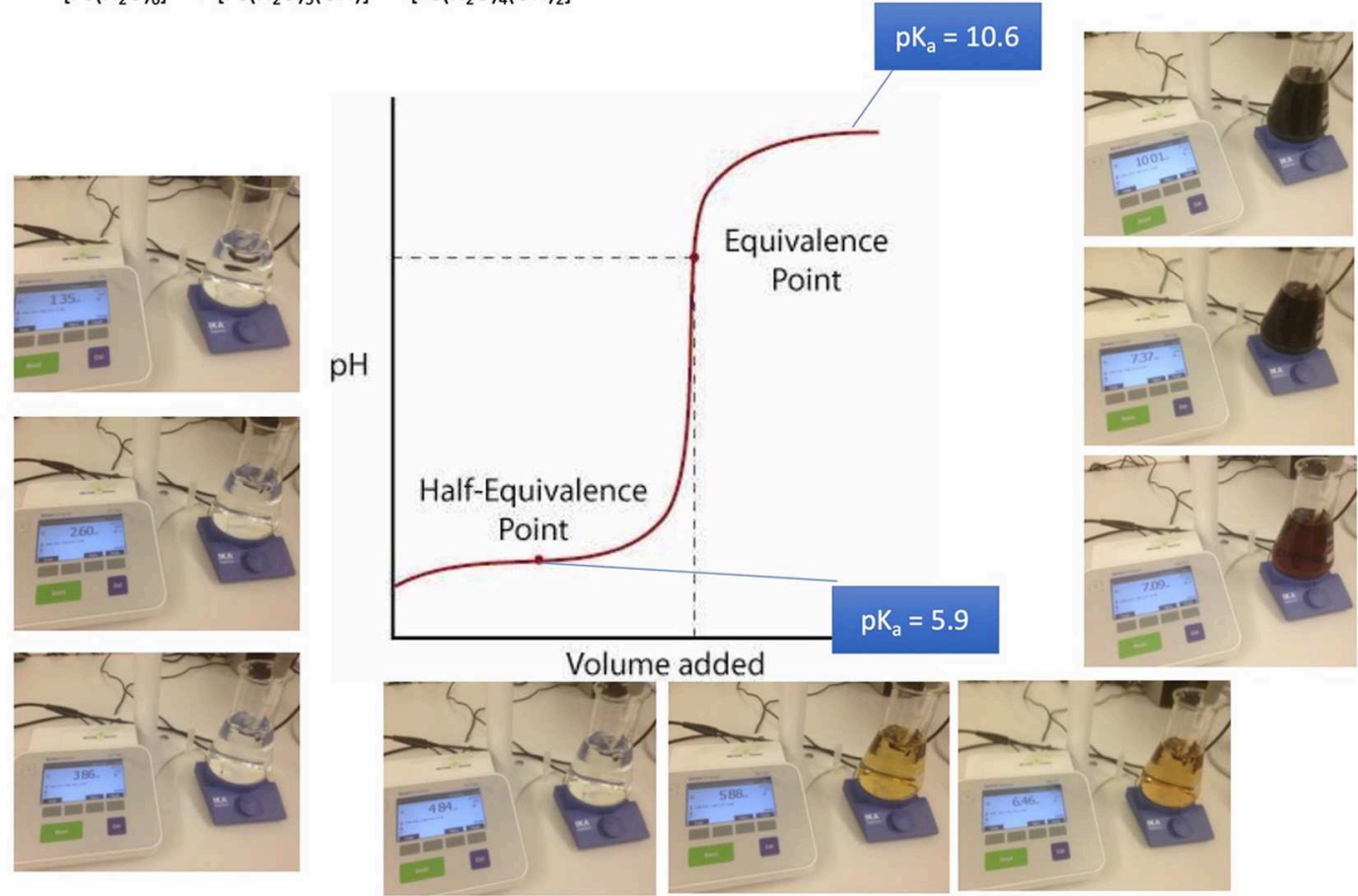

FIGURE 2 | Absorption and bioavailability of iron. "Free" iron exists in aqueous solutions as aquo-complexes and is therefore an acid which deprotonates step by step. It solubility depends on its oxidation state and $\mathrm{pH}$. (A) Precipitation of iron-(III)-aquo-complexes starts already at fairly acidic conditions. This leads to a loss of solubility decreasing from the acidic environment in the stomach and the proximal parts of the duodenum. An amorphous mass once precipitated cannot be absorbed from the Gl tube an more. (B) Precipitation of iron-(II)-aquo-complexes are becoming critical only at neutral an alkaline conditions. Ferrous iron condensates only at such conditions. This is the reason why ferrous iron is absorbed more readily than ferric iron which is at these pH conditions already precipitated. Ferrous iron is therefore suitable for iron-anemia treatment. 
are observed before birth (50). For this stage of ontogeny and of neonatology, no information about a gender impact nor about ethnical variability is available.

Full peptic digestion capability develops after 2 years only, whereas antisepsis due to low $\mathrm{pH}$ in the stomach is immediately built up after birth: "In full-term babies, gastric acidity changes within $1 \mathrm{~h}$ from 6.1 to 5.4 , within $2 \mathrm{~h}$ to 3.1 , and within $6 \mathrm{~h}$ to 2.2 . $\mathrm{pH}$ increases afterwards for 10 days and goes down again only slightly. Acid output similar to adults is reached by 24 weeks. $\mathrm{pHs}$ were measured either by potentiometry or by titration in older methods (51-54). Results should be equally reliable with either one of the methodologies of measurement. "Pre-term born babies have a gastric $\mathrm{pH}>4$ for $80-90 \%$ of time, the acidity only rising with age" (55).

Bottle-fed babies have a similar gastric $\mathrm{pH}$ to breast-fed babies. "An increase in gastric $\mathrm{pH}$ to around 4.0 is observed for infants between 1 and 12 months with chronic diarrhea and protein malnutrition, combined with bacterial overgrowth essentially with Gram-negative bacilli, in $57 \%$ of the cases. The bacterial overgrowth happens at the moment of the evolution of the disease to a chronic state. Breast-fed babies do not have bacterial overgrowth of gram-negative bacilli and no diarrhea" (56). This bacterial overgrowth is favored by bottle-feeding with formula products, as immunoglobulins from lactating mothers and timely physiological $\mathrm{pH}$ adaption are lacking. In addition, children aged 4-36 months suffering from GERD (gastro-esophageal reflux disease) and treated with $\mathrm{H}_{2}$ antagonists or PPIs for 8 weeks showed a higher risk for acute gastroenteritis and pneumonia, although otherwise healthy. These risks persist after stopping the therapy (39).

\section{Childhood}

Prepubertal childhood. There is a gender difference in prepubertal oligo-element absorption: In the fasting state, male preadolescents absorb $35.2 \%$ and female preadolescents $45 \%$ of an iron loading dose. As supplement in a meal, preadolescent men absorb $14.8 \%$ and preadolescent women $24.7 \%$ of a dose. Serum ferritin differed only marginally in this study. As a result, iron anemia is as high as $12.1 \%$ in boys aged $11-15$ and only $6.1 \%$ in girls of the same age (57).

Pubertal childhood. Hormonal biosynthesis and changes all over life is mirrored not only by body morphology, but also by the extra-hepatic regulation of metabolic processes. The breast consists of differently developed lobes and is equipped with the adequate CYP isoenzymes such as aromatase to locally biosynthesize steroids from circulating precursors. These hormones are liberated and systemically measurable. Estradiol and progesterone bind to their receptors $\mathrm{ER} \alpha, \mathrm{ER} \beta, \mathrm{PR} A$, and PR B and initiate the cell signaling cascade finishing up in the cell nucleus. Estrogens induce the ductal development, progesterone the lobes and alveolus. Type $1(65-80 \%)$ and type 2 lobes (10$35 \%)$ predominate in child-less women. Type 3 dominates (70$90 \%)$ in women after delivery. In the menopause, involution occurs, and type 1 dominates again. Risks for breast cancer are an early menarche, a late menopause, and a higher age at the first pregnancy. A protection is evident from an early pregnancy and delivery (58).

\section{Adulthood}

Ovulation-suppressed women. Apart from iron, another important co-factor of enzymes is copper. In the age group of 20-59 years old persons, its absorption is generally higher in women $(71 \%)$ than in men $(64 \%)$. This difference disappears later in life at the age between 60 and 83 years. Copper and ceruloplasmin plasma levels of women aged between 20 and 39 years taking ovulation suppressors tend to be higher than in women with physiological cycles (59).

Estradiol suffers from an extensive hepatic first-pass effect. As a result of its low bioavailability of $<10 \%$, its derivative Ethinylestradiol is the most widely used estrogenic component of combined oral contraceptives. The absorption process differs individually in length (1-2h), extent (generally around 90\% bioavailability), and the time for reaching the maximum peak of blood level (1-2h mostly, with observed lag times of up to $6 \mathrm{~h}$ ). Steroid concentration in the portal vein blood after absorption and hepatic first-pass is still 25-65\% of the amount ingested and has an effect on several globulins such as thyroid binding, sex hormone binding, corticosteroidbinding globulins, angiotensinogen, as well as coagulation and fibrinolytic factors. 2-hydroxylations by CYP3A4 and CYP2C9 dominate with wide individual variation, whereas 4-, 6-, $16 \alpha-$, and $16 \beta$-hydroxylations are compromised to physiological estradiol. Besides glucuronidation, sulfate-conjugates at positions 3 and 17 are readily built and are 10 -fold more concentrated in the circulation than ethinylestradiol itself. Partially, to 11 and $21 \%$, respectively, the sulfates are deconjugated to ethinylestradiol during enterohepatic recirculation. Plasma levels of ethinylestradiol differ markedly between ethnic groups. Highest plasma levels were found in Nigerian women, lowest in women from Thailand. Nigerian women excreted mainly conjugates of ethinylestradiol and hardly any oxidation derivatives (58).

Progestins used for contraception and/or post-menopausal hormone replacement therapy vary widely in structure, absorption and metabolism. Large inter- and intrasubject variability is observed. The $\mathrm{C}_{\max }$ is reached within 1-3 h. Plasma levels are between $70 \%$ and more than $90 \% . \mathrm{T}_{1 / 2}$ differs from between 8 and $12 \mathrm{~h}$ for norethindrone and dienogest to between 50 and $80 \mathrm{~h}$ for cyproterone acetate (60).

Obesity is considered an inflammatory disease with elevated levels of some cytokines such as IL-6 and TNF. Cytokines are known as transcriptional regulators of the CYP450 expression. In addition, fatty livers might affect the function of hepatic isoenzymes. A decrease of activity is reported for CYP3A4,5,7 and CYP2E1, whereas the efflux transporter P-gp is expressed higher. Although CYP450 isoenzymes' activity decreases and conjugation increases, the "one dose fits all" approach is applicable in both obese and normal weight women, as oral contraceptives influence the hypothalamic-pituitaryovarian axis and the feedback loops similarly with a tendency toward more follicle maturation in obese women (60). A higher part of hormonal contraceptives is distributed toward the fat mass in obese subjects. This bears a higher risk of hormonal contraceptives failure as contraceptives' plasma levels decrease. However, no difference in distribution volumes 
of ethinylestradiol and levonorgestrel between normal and obese BMI subjects could be demonstrated. Instead, the time to reach the levonorgestrel steady-state was found to be adversely affected by obesity and the half-life in obese subjects was twice as long. While peak levels of oral contraceptives (ethinyl estradiol and levonorgestrel) are somewhat lower in obese women (BMI 30.0-39.9) compared to normal weight women (BMI 19.0-24.9), the through levels over the cycle are similar. The small pharmacokinetic differences do not activate ovarian follicles (61).

Pregnancy. "As a result of hormonal changes, pregnant women often suffer from heartburn induced by reduced esophageal sphincter pressure and heartburn due to sex hormones, essentially progesterone" (62). "In this patient group, short-term acid neutralizers or $\mathrm{H}_{2}$-antagonists should be preferred instead of PPIs in possibly meal-free phases in order to omit the risk of incomplete protein digestion and the risk of predisposition to immune responses of the child. This risk is indeed confirmed in a Swedish study correlating the incidence of allergy and asthma of babies with anti-ulcer consumption of their mothers during pregnancy." The allergy incidence of the discharged children was $5.03 \%$. This significance was shown by an odds-ratio (OR) of 1.43 with a $95 \%$ confidence interval (1.29-1.59). The development of childhood asthma is higher in exposed children $(5.6 \%)$ than in the population (3.7\%), statistically validated by OR $1.51,95 \%$ CI $1.35-1.69$ (63).

\section{Metabolism}

To cope with food-derived interaction variability, all 57 CYP450 isoenzymes should be assessed. In addition to pharmacotherapeutically relevant CYP450 isoenzymes such as those listed in the Flockhart tables (64), substrates, inhibitors and inducers originating from food, e.g., anthocyanidins, flavonoids, vitamins A, B1, B2, D, E, brassica species (broccoli, Brussel sprouts, cauliflower), chargrilled meat, tobacco, ethanol, St. John's wort, grapefruit juice, or Cassia (Chinese) cinnamon, and many more have to be of interest to nutritionists and nutritional medicine. In clinical nutrition, not only deficits are challenging, but too much intake as well. Well-known to endocrinologists were the goiter inducing brassica factors of mustard oil glycosides from brassica species. This effect was triggered by thiocyanate liberated and competing with iodine for the thyroid peroxidase catalyzed iodination of thyroglobulin (65).

Metabolic reactions are predominantly assumed by the cytochrome P450 superfamily. P450s are present in Homo Sapiens, and over 4500 individual members are known in all living species. " 450 " relates to the Soret region in the absorption spectra of these enzymes where their $\lambda_{\max }$ are located. CYP450s are classified into 18 families and 43 subfamilies. Apart from gene expression and the phenomenon of polymorphism, gender and age have an impact on the activity and thus on inter-individual variation. Members of the families CYP1, CYP2, and CYP3 are polyvalent and therefore suitable for metabolic transformation of a large number of drugs and structurally diverse xenobiotics, whereas the families CYP11, CYP17, CYP19, and CYP21 tend to have only a few substrates, predominantly their physiological substrates, i.e., steroid hormones, and to be therefore highly specific (66). This enzymatic polyvalence is clinically important mainly for toxicological reasons. However, these enzymes may be saturated and become rate-limiting pacemakers. Substrates may accumulate and adverse side effects may arise from increasing blood levels of the substrates. Inhibition may be established within a few days. Induction develops more slowly, in general within some weeks (12).

Metabolism is discussed mainly in terms of the hepatic part due to its predominance, although it happens also in extra hepatic hormone dependent tissues, e.g., CYP2S1 in epithelial tissues, mainly skin, but also kidneys, intestines, lungs, nasal epithelium. This is the reason why efficacy of pharmacotherapy may depend on target tissues, e.g., retinoids in skin. Hepatic and intestinal P-gp and other transporters are expressed to a higher degree in men than in women. In men, some isoenzymes have a higher activity, due to induction, e.g., CYP1A2, CYP2C9, CYP2E1. CYP1A2 can be induced to be 40 times as active in case of a high charcoal-grilled meat consumption. In women, some CYP450 isoenzymes are more expressed than in men, e.g., CYP3A4,5,7 as a function of the menstrual cycle with top level before ovulation and in pregnancy, CYP2A6, CYP2B6, or CXP2D6, which is highly expressed only in the fertile phase, CYP3A4,5,7.

Inconsistent data seem to arise from cross-influences of Pgp and CYP3A4,5,7. The efflux glycoprotein and the CYP450 isoenzymes are co-localized. Thus, in clinical studies evaluating both transporting P-gp and metabolizing CYP3A4,5,7 care has to be taken to omit confounding (25). Research on nutrients in this domain is scarce and remains to be established. The reason might be a lack of using histological and cell-biological methodologies in nutrition research as compared to in vitro human liver models currently used in pharmacological and pathological research (11).

\section{Biochemistry of cytochromes P450}

Cytochrome P450 isoenzymes are tetramethylated hemoproteins, such as cytochrome c, ferriprotoporphyrin IX, hemoglobin, or myoglobin, with iron (+III) as central atom, and widely distributed throughout the biological world. From 1980, CYP450's crystal structures were solved for 54 unique structures (67). Subtle changes from one molecule to a closely related one generally lead to drastic changes in behavior, i.e., to different groups of hemoproteins such as monoxygenases (= mixed-function oxygenases), peroxidases, peroxygenases, and oxygen carriers. Typical enzymatic cycles and intermediate compounds involved provide highly reduced oxygen derivatives as an oxidant (Figure 3). However, CYP450 isoenzymes do not only act as monooxygenase to detoxify. Today's knowledge hints at a more complex role in regulation on hepatic and extra-hepatic tissues.

The central iron atom of hemoproteins carries oxygen in different oxidation states, i.e., as reactive oxygen species which either oxidize substrates of the enzymes compounds I and II by $1 \mathrm{e}^{-}$or $2 \mathrm{e}^{-}$donations, respectively, or contribute to irreversible enzyme inactivation in case of excess substrate by the enzymes compound III. Inactivation of the enzyme occurs by cleaving the heme moiety and liberating iron which in turn 


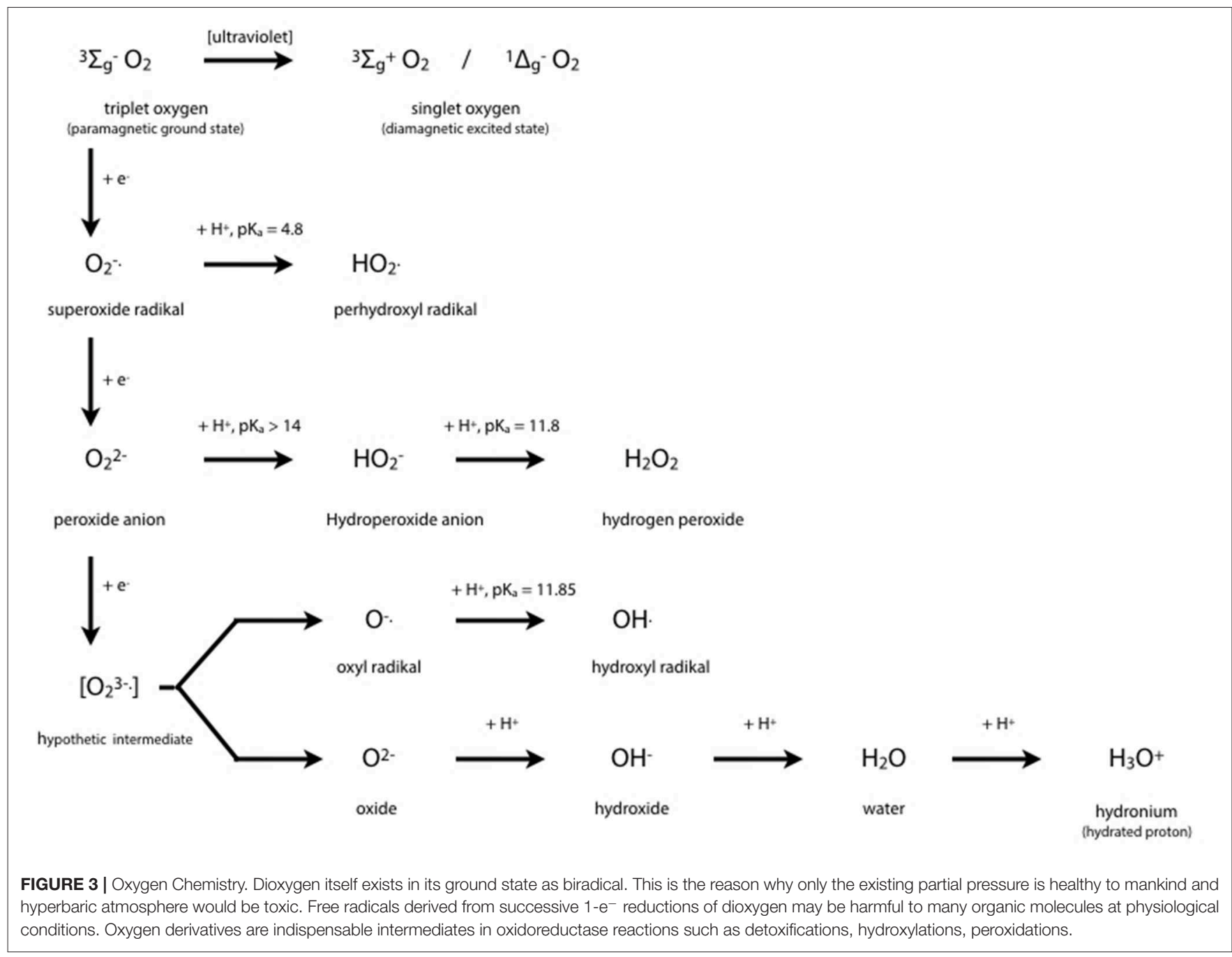

contributes to Fenton-like reactions producing highly oxidative hydrogen radicals:

$$
\mathrm{Fe}^{2+}+\mathrm{H}_{2} \mathrm{O}_{2} \rightarrow \mathrm{Fe}^{3+}+\mathrm{OH}+\mathrm{OH}^{-}
$$

Copper may substitute for iron. It yields an even faster production of hydroxyl radical (65).

Monooxygenation require NADHP and $\mathrm{O}_{2}$ (Figure 4A):

$$
\mathrm{RH}+\mathrm{O}_{2}+\mathrm{NADPH}+\mathrm{H}^{+} \rightarrow \mathrm{ROH}+\mathrm{H}_{2} \mathrm{O}+\mathrm{NADP}^{+}
$$

To bind dioxygen, the prosthetic group must be reduced from the ferric to the ferrous state by a first $1-\mathrm{e}^{-}$transfer from NADPH. Another $1-\mathrm{e}^{-}$transfer from NADPH induces a structural rearrangement of the high electron-density on the $\pi$-system and the shift of the density on the dioxygen which leads to O-O bond cleavage. One of the oxygens is liberated and protonated to form water. The remaining oxygen is configured as highly reactive ferryl intermediate $(\mathrm{Fe}=\mathrm{O})$. This ferryl intermediate obtains a hydrogen atom from the substrate RH. After the hydrogen release the substrates forms a radical intermediate which in turn captures the preformed hydroxyl group from the enzyme intermediate to form the hydroxylated substrate. The release of $\mathrm{OH}$ brings iron back to the ferric state (68). Thus, one of the oxygen of dioxygen will end up as hydroxyl function in the substrate. The second oxygen atom will be reduced to water.

Mono-oxygenation can be performed by a peroxide shunt as an alternative. Single oxygen donation from substrates such as peroxides lead to the shortly living and hardly detectable $\pi$-cation radical compound I. This shunt resembles to a peroxidative cycle as depicted for lactoperoxidase (LPO) (Figure 4B). In peroxidases, the catalytic cycle of P450 isoenzymes starts on binding the substrate, seen as a spectral change. $\mathrm{e}^{-}$source is $\mathrm{NAD}(\mathrm{P}) \mathrm{H}$ via cytochrome $\mathrm{P} 450$ reductase. The reduction equivalent of iron is situated mainly paired in d-orbitals to yield the low spin ferrous state. Molecular dioxygen is bound covalently. Another $\mathrm{e}^{-}$transfer reduces the dioxygen adduct, which is rapidly twice protonated, and liberates water. The resulting intermediate correlates to the highly reactive $\pi$-cation radical compound I which catalyzes any further reaction, e.g., a hydroxylation. From compound I upon release of the product, the enzyme reconverts to the resting state (70). The normal 


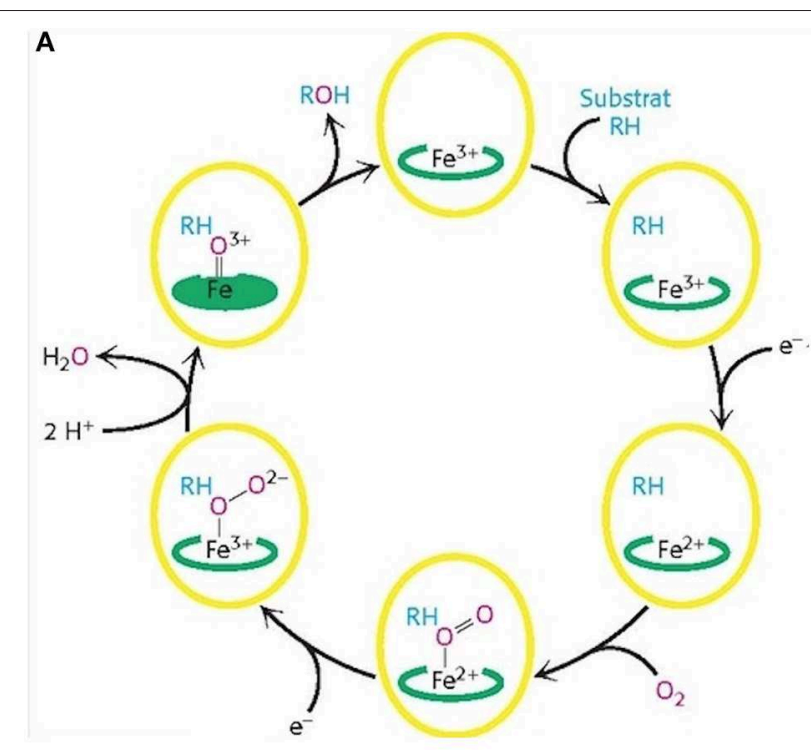

B

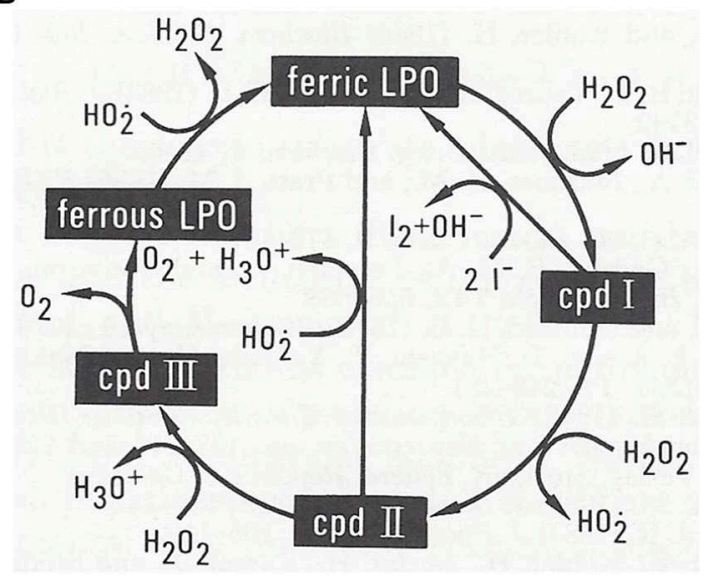

FIGURE 4 | Outline of the catalytic cycles of oxidoreductases. (A) Hydroxylation of substrates of aromatase requires the activation of oxygen. This activation is promoted by the heme prosthetic porphyrin ring system. An electron transfer reduces the ferric to the ferrous intermediate state, which enables iron to bind dioxygen. Another electron transfer induces a rearrangement of the highly electron-dense $\pi$-system and cleavage of the O-O bond. One of the oxygens is protonated and liberated as water. The remaining oxygen is configured as ferryl intermediate which extracts a hydrogen atom from the substrate. A transient radical of the substrate thus formed captures the $\mathrm{OH}$ group from the enzyme intermediate to end up as hydroxylated substrate. With the permission of Berg et al. (68). (B) Pathways in lactoperoxidase-catalyzed $\mathrm{H}_{2} \mathrm{O}_{2}$ metabolism. I- reacts with compound I by direct $2 \mathrm{e}^{-}$transfer. The normal peroxidatic cycle includes ferric lactoperoxidase -> compound I -> compound II -> ferric lactoperoxidase. $\mathrm{H}_{2} \mathrm{O}_{2}$ in excess leads to formation of compound III and reconversion to the resting enzyme via the ferrous state. Compound III pathway is combined with irreversible inactivation of the enzyme. The conceivable structures of the heme moieties of lactoperoxidase's ground state and intermediate enzymatic compounds show a movement of iron out of plane (not depicted) $(65,69)$.

peroxidatic cycle includes ferric lactoperoxidase $->$ compound I $->$ compound II $->$ ferric lactoperoxidase. $\mathrm{H}_{2} \mathrm{O}_{2}$ in excess leads to formation of compound III and reconversion to the resting enzyme via the ferrous state. Compound III pathway is combined with irreversible inactivation of the enzyme (69). The heme moieties of lactoperoxidase's resting ground state and of its intermediate compounds are characterized by the conceivable movement of iron out of plane which impacts solubility and reactivity (65).

\section{Excretion}

As absorption and excretion sum up to a typical Batemanshaped curve representing the plasma level of a single dose, there is a complex interrelation and regulation of biochemical pathways. Isolated views lead to erroneous interpretations of pathophysiological situations. A typical example is the assessment of the impact of salt intake on the highly publichealth-relevant hypertension. Both excess and insufficient supply of sodium are recognized as inductors of non-communicable diseases. However, this does not yet qualify only intake nor excretion as the only reasons of hypertension. The question is rather what comes first, overconsumption of unhealthy foodstuff as inductor of cardio-vascular deterioration followed by manifest diseases, or rather the other way around, i.e., heart and kidney insufficiencies followed by the inability to excrete sodium efficiently. So far, not enough evidence has been presented for neither one of the two theses. It is likely that individual histories differ. Corresponding clinical studies suffer almost generally from systematic errors such as biases and confounding factors as well as unprecise exposure and outcome conditions. A study claiming that BMI is the main contributory modifiable factor of blood pressure level included in a meta-analysis 8,670 volunteers from a network-questionnaire on age-adjusted associations of hypertension and life-style. The questionnaire included a 3 times $24 \mathrm{~h}$ recall of dietary intakes. The outcome was a claim of hypertension being associated with elevated BMI, age, and education and of salt not being associated with systolic blood pressure in either sex after multiple adjustments (71). Another study did not find a hypertension lowering effect of low sodium intake in a particular regional study (72). The contrary claim that salt reduction lowers blood pressure was issued as a result of a meta-analysis including 3,220 participants in 34 trials. These participants reduced their daily salt consumption to $4.4 \mathrm{~g}$ for 4 weeks. The results reported and interpreted included a reduction of systolic blood pressure of -4.2 to $-2.1 \mathrm{~mm} \mathrm{Hg}$ over all, of -5.4 to $-2.8 \mathrm{~mm} \mathrm{Hg}$ in hypertensive participants, and of -2.4 to $-1.0 \mathrm{~mm} \mathrm{Hg}$ in normotonic participants (73). These marginal changes do not seem to be highly reliable. They contribute to implausible results in human nutrition research $(4,7)$. It is advisable to issue no claim at all actually due to insufficient proofs from both observational and experimental studies (74):

- Blood pressure changes reported are modest and variable

- Effect seems to be more distinct in the elderly and in subjects suffering from higher blood pressures

- There is no evidence that a salt intake reduction is safe or cardioprotective

- There is no comparison of cardioprotective, safe, efficacious, and economical medicines indicated in hypertension 

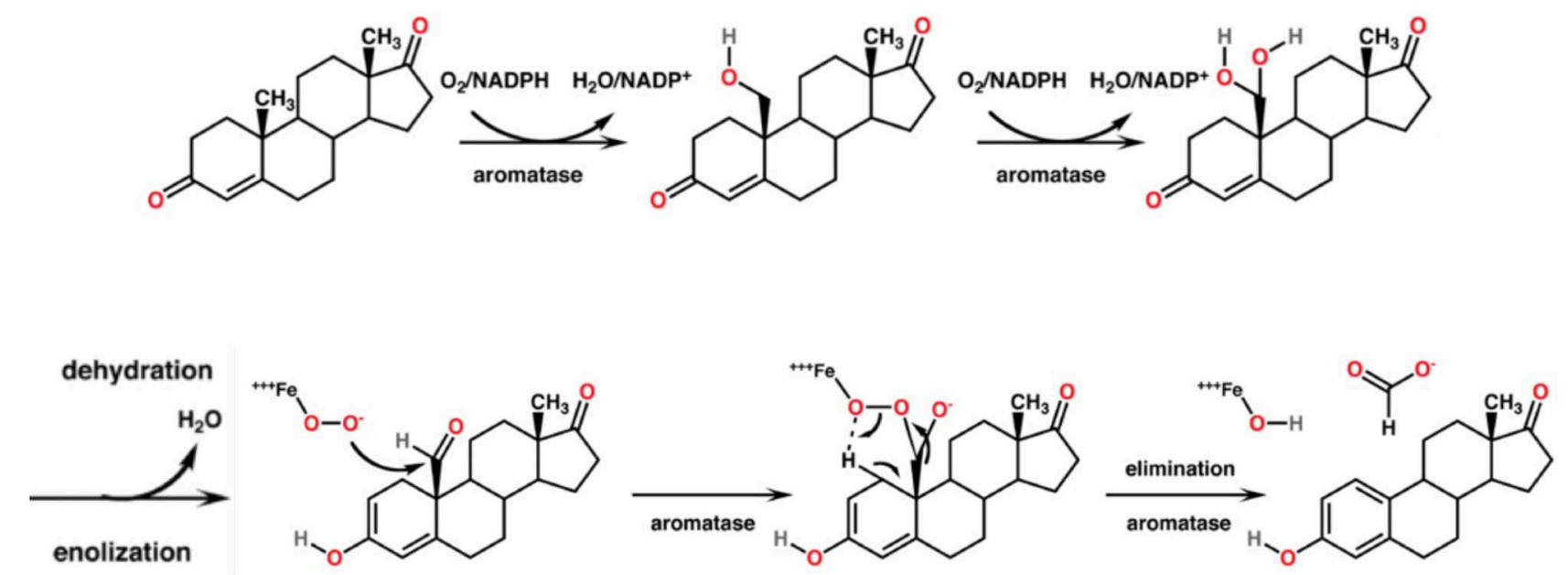

FIGURE 5 | Mechanism of the aromatase-catalyzed enzymatic biosynthesis of 17 $\beta$-estradiol from its androgenic precursor testosterone. The $\alpha, \beta$-unsaturated ketone of ring $\mathrm{A}$ of the steroid is transformed to a phenolic structure. The biosynthesis consists of three consecutive reactions, two hydroxylations followed by a $\mathrm{C}-\mathrm{C}$ bond cleavage.

- There is no convincing outcome assessment focused on the length and quality of life that would justify a public health recommendation to a whole population rather than to a selection of individuals in the context of personalized nutritional medicine

\section{Pharmaco- and Nutrient-Dynamic Considerations Steroid Metabolism, Aromatase, Estradiol Receptors, and Breast Cancer}

CYP19A1, syn. Aromatase, is the CYP450 isoenzyme catalyzing the transformation of testosterone and androstenedione to estrone and estradiol. The enzymatic reaction consists of a concomitant demethylation and sterol ring $\mathrm{A}$ aromatization starting with two conventional hydroxylations yielding the 19hydroxymethyl derivative of the substrate and a 19-gem-diol, which rapidly decays to an aldehyde. This one is cleaved at the C-C bond at $\mathrm{C} 19$ yielding formic acid which has incorporated both oxygens enzymatically from molecular oxygen (75). The monooxygenation is depending on the activation of molecular oxygen in CYP450 isoenzymes [(76); Figure 5]. The catalytic site in vivo consists of iron chelated as porphyrin derivatives. Nitrogen compounds replacing porphyrin as chelator are interesting candidates in chemical in vitro research as reaction kinetics differ markedly. Such candidates are deferiprone, deferoxamine, deferasirox (77).

The main targets of medicines indicated in breast cancer are aromatase (by aromatase inhibitors, e.g., tamoxifen) and selective estrogen receptors (modulated by selective estrogen receptor modulators SERMs). 17 $\beta$-estradiol (E2) is the most biologically potent estrogen in breast tissue. However, breast cancer and highest E2 blood levels are not directly correlated. Most women develop breast cancer after the menopause. In this phase of life, remaining E2 plasma levels are 10 times lower due to ovarian exhaustion. Thus, the uptake of E2 from ovarian biosynthesis via blood stream into the mammary gland is unlikely to be responsible for local estrogen concentrations in breast tumors. Another mechanism must be the causation of neoplasms. It is more likely that "hot spots" of aromatase become highly active to increase the intra-tumor biosynthesis of estrogens from the precursors testosterone and androstendione circulating in the plasma $(58,78)$. Thus, the neoplasm itself induces a local production of aromatase which increases in turn the effectiveness of therapeutically and preventively used aromatase inhibitors. Apart from CYP19A1, a mixedfunction monooxygenase, tumorigenesis has been explained as an effect of lactoperoxidase present in the mammary glands, a peroxidase, oxidizing estrogens at the 3-hydroxylgroup to free radicals (79).

Aromatase inhibitors are the therapy of choice for most postmenopausal breast cancer patients. It may be accompanied by an adjuvant therapy with aromatase inhibitors from plants. Alone, these aromatase inhibitors from plants are suitable to contribute for long-term breast cancer prevention [(13, 24); Figure 6]. However, enhancement or reduction of the enzyme activity or its protein expression by food ingredients is an understudied issue. There are a couple of structure requirements substrates should fulfill in order to interact with aromatase to exert an activity, either an effect or an inhibition $(77,80)$ :

- $\alpha$-/ $\beta$-unsaturated ketone function

- This provides a flat configuration. Therefore, an aromatic ring system is also suitable

- Z-conformation at the double bond

- An asymmetric center $\left({ }^{*} \mathrm{C}\right.$, spiro, chock, or ansa configuration in position $\gamma$ to the ketone) wearing a methyl substituent. Testosterone is according to IUPAC rules (1S,2R,10R,11S,14S,15S)-14-hydroxy-2, 
<smiles>C[C@]12CCC(=O)C=C1CC[C@@H]1[C@@H]2CC[C@]2(O)C(=O)CC[C@@H]12</smiles>

\section{4-Androstene-3,17-dione}

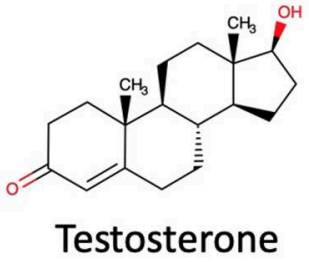

Testosterone

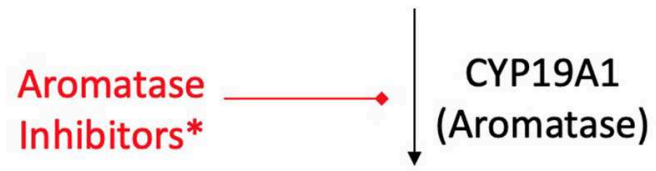<smiles>C[C@]12CC[C@H]3c4ccc(O)cc4CC[C@H]3[C@@H]1CCC2=O</smiles>

Estrone
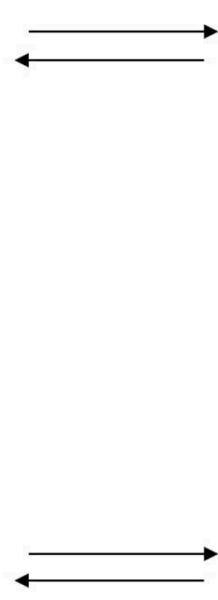

*Aromatase Inhibitors (steroidal, non-steroidal, stilbenoid)

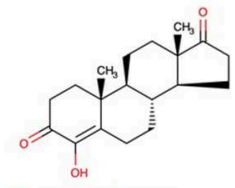

Formestane

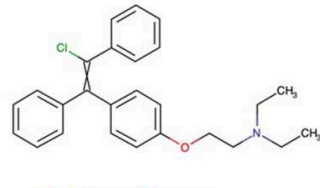

E-Clomifene

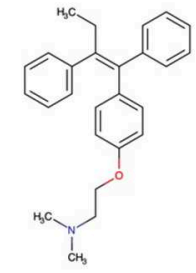

Z-Tamoxifen

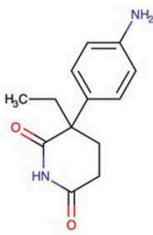

Aminoglutethimide

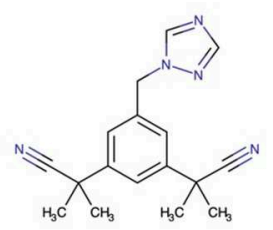

Anastrazole

\section{Aromatase Inhibitors*}

FIGURE 6 | Aromatase and aromatase inhibitors. Estradiol and estrone are enzymatically biosynthesized by aromatase (CYP19A1) from androgenic precursors. Aromatase inhibition is the current pharmacotherapy and suitable prevention of breast cancer. There are more than 30 enzymatic reactions upstream, downstream, and sidestream of the aromatase reactions. Therefore, an delicate equilibrium in the hormonal status is highly regulated and fine-tuned.

15-dimethyltetracycloo[8.7.0.0^\{2,7\}0.0^\{11,15\}]

heptadec-6-en-5-on

- Steroid binding site located on the apoprotein

- The aromatase substrate must fit into this 3D-structure.

\section{Flavonoids as Inhibitors of Estradiol's Action}

Aromatase is a target of flavonoid bioactives. Flavonoids' 3-dimensional partial structure ressembles the physiological substrates of aromatase, i.e., testosterone and androstenedione. Flavonoids compete therefore for aromatase and enhance or inhibit modulators of $17 \beta$-estradiol receptors $\mathrm{ER} \alpha$ and ER $\beta$. The inhibitory effect on the enzyme needs a structural relationship between androstendione or testosterone and a partial structure of flavonoids (Figure 6). As a result, inhibitors and natural substrates compete for the enzyme and antagonize the transformation of the physiological substrates to estrogens. The mechanism of action of flavonoids is currently described as antioxidative effect. In fact, as the oxygen cannot be transferred from the enzyme's intermediate compound to the substrate but to the competing flavonoid, this explanation is in line with the competitive antagonism explanation and the classical pharmacological interaction concept.

Aromatase inhibitor stereochemistry and quantitative conditions at the target are essential to determine the effect it will have on the development of breast cancer. When using aromatase inhibitors, estrogen levels decrease in the plasma and locally in breast "hot spots," decreasing the outbreak or progression of breast cancer. In addition to the pharmacochemical aromatase inhibitors, there are many natural components that can perform the same action, eventually with fewer adverse effects (81).

Inhibitory effects on aromatase have been described for many plants, mostly containing polyphenols/flavonoids [(82-84); Table 1]. The most popular plants are:

- (Green) tea and soy intake as a result of the active principles caffein, calcitriol, ellagitannins, flavonoids/polyphenol/isoflavones 
TABLE 1 | CYP19A1 active food ingredients, their targets, and effect on the enzyme: Substrate (S), Inhibitor (-), Inducer (+).

\begin{tabular}{|c|c|c|}
\hline Plant and active ingredients & Targets & $\begin{array}{l}\text { Effect on } \\
\text { aromatase }\end{array}$ \\
\hline $\begin{array}{l}\text { Allium species, containing allicin, S-allyl } \\
\text { cysteine, S-allyl mercaptocystein, } \\
\text { organosulfides (diallyl mono-, di-, trisulfide) } \\
\text { - A. sativum = Garlic } \\
\text { - A. ursinum = Wild garlic }\end{array}$ & $\begin{array}{l}\text { Cell signaling } \\
\text { Glutathiontransferase } \\
\text { Apoptosis }\end{array}$ & 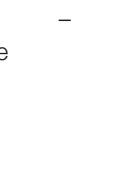 \\
\hline $\begin{array}{l}\text { Brassica species [Cruciferous vegetables } \\
\text { (mainly sprouts)], containing indole-3 } \\
\text { carbinol, organosulfides, sulpharophanes, } \\
\text { isothiocyanate from glucosinolates } \\
\text { - Broccoli } \\
\text { - Brussels sprouts } \\
\text { - Cauliflower } \\
\text { - Kale and bock choy }\end{array}$ & $\begin{array}{l}\text { Aromatase } \\
\text { Cell signaling } \\
\text { Glutathiontransferase } \\
\text { Angiogenesis } \\
\text { VEGF receptor } \\
\text { NF-к B } \\
\text { Apoptosis }\end{array}$ & e \\
\hline $\begin{array}{l}\text { Citrus spp., containing prolin, betain, } \\
\text { naringenin, monoterpenes, D-limonene } \\
\text { - Grapefruit } \\
\text { - Orange } \\
\text { - Mineola }\end{array}$ & $\begin{array}{l}\text { Aromatase } \\
\text { COX-2 } \\
\text { Cell signaling }\end{array}$ & - \\
\hline $\begin{array}{l}\text { Coffee, containing melatonin, and } \\
\text { melanoidins }\end{array}$ & $\begin{array}{l}\text { Aromatase } \\
\text { COX-2 } \\
\text { Cell signaling } \\
\text { Metabolic } \\
\text { regulation }\end{array}$ & - \\
\hline $\begin{array}{l}\text { Curcuma domestica and C. longa (Turmeric), } \\
\text { containing curcumin }\end{array}$ & $\begin{array}{l}\text { COX-2 } \\
\text { ROS scavenging }\end{array}$ & - \\
\hline $\begin{array}{l}\text { Fruits (pigmented) and berries, containing } \\
\text { ellagitannin, ellagic acid, sitosterol, } \\
\text { anthocyanidines (delphinidine, myrtillin), } \\
\text { phenolic acids } \\
\text { - Urolithin B in pomegranate, } \\
\text { - Rubus ssp.: lambertianin C in } \\
\text { blackberries, sanguinin H-6 in } \\
\text { raspberries, myrtillin in blackcurrant } \\
\text { pomace } \\
\text { - Fragaria } \times \text { ananassa Duch.: agrimoniin) }\end{array}$ & $\begin{array}{l}\text { Aromatase } \\
\text { COX-2 } \\
\text { Cell signaling } \\
\text { Glutathiontransferase } \\
\text { Angiogenesis/VEGF } \\
\text { NF-к B } \\
\text { Apoptose }\end{array}$ & e \\
\hline Ethanol & Aromatase & + \\
\hline 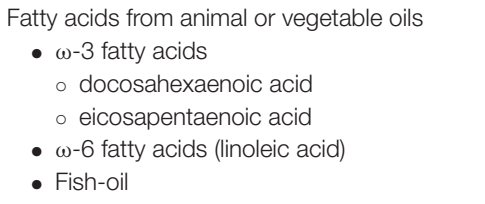 & $\begin{array}{l}\text { Nuclear receptor } \\
\text { Anti-oxidation }\end{array}$ & - \\
\hline Grape seed, containing resveratrol & $\begin{array}{l}\text { Aromatase } \\
\text { COX-2 } \\
\text { ROS scavenging }\end{array}$ & - \\
\hline $\begin{array}{l}\text { Green Tea, containing } \\
(-) \text {-epigallocatechingallate }\end{array}$ & Aromatase & - \\
\hline $\begin{array}{l}\text { Honey, sugarcane molasses containing } \\
\text { melatonin and melanoidins }\end{array}$ & $\begin{array}{l}\text { Aromatase } \\
\text { COX-2 } \\
\text { Cell signaling } \\
\text { Metabolic } \\
\text { regulation }\end{array}$ & - \\
\hline $\begin{array}{l}\text { Liquorice (Glycyrrhiza glabra), containing } \\
\text { glycyrrhizin, Glycyrrhic acid }\end{array}$ & Aromatase & + \\
\hline $\begin{array}{l}\text { Mushrooms } \\
\text { - Agaricus bisporus (= white or brown } \\
\text { button, baby button, portobello, crimini, } \\
\text { champignon de Paris) }\end{array}$ & Aromatase & - \\
\hline
\end{tabular}

(Continued)
TABLE 1 | Continued

\begin{tabular}{|c|c|c|}
\hline Plant and active ingredients & Targets & $\begin{array}{l}\text { Effect on } \\
\text { aromatase }\end{array}$ \\
\hline $\begin{array}{l}\text { - Lentinula edodes = Agaricus edodes (= } \\
\text { shiitaki, Chinese black mushroom, } \\
\text { golden oak mushroom) }\end{array}$ & & \\
\hline $\begin{array}{l}\text { Nuts, containing fatty and amino acids (e.g., } \\
\text { arginine) } \\
\text { - Walnut } \\
\text { - Hazelnut } \\
\text { - Cashew }\end{array}$ & $\begin{array}{l}\text { Nuclear receptor } \\
\text { VEGF receptor }\end{array}$ & - \\
\hline $\begin{array}{l}\text { Soy, containing phytoestrogens, stilbenes, } \\
\text { and genistein }\end{array}$ & Aromatase & - \\
\hline Testosterone (and Androstenedione) & Aromatase & S \\
\hline $\begin{array}{l}\text { Ubiquitary occurrence: Flavonoids. } \\
\text { Polyphenols } \\
\text { - Flavonols (kaempferol, rutin, myricetin, } \\
\text { quercetin, spirenoside, galangin, } \\
\text { rhamnetin) } \\
\text { - Flavonones (hesperitin, naringin, } \\
\text { naringenin, hesperidin) } \\
\text { - Flavones (apigenin, flavone, luteolin, } \\
\text { chrysin, diosmetin, diosmin) } \\
\text { - Flavonolols (silibinin, silymarin, taxifolin) } \\
\text { - Flavan-3-ols (catechin) } \\
\text { - Isoflavones (genistein) }\end{array}$ & $\begin{array}{l}\text { Aromatase } \\
\text { COX-2 } \\
\text { Anti-oxidation }\end{array}$ & - \\
\hline $\begin{array}{l}\text { Vitamins A, C, E, and provitamins, e.g., } \\
\text { lycopene (= } \Psi, \Psi \text {-carotene), beta-carotene, } \\
\text { xanthophylls, tomatine, solanin } \\
\text { - Tomato (Solanum lycopersicum) } \\
\text { - Watermelon } \\
\text { - Cantaloupe } \\
\text { - Pink grapefruit } \\
\text { - Papaya } \\
\text { - Apricot } \\
\text { - Carrots } \\
\text { - Banana }\end{array}$ & $\begin{array}{l}\text { Aromatase } \\
\text { COX-2 } \\
\text { Cell signaling }\end{array}$ & - \\
\hline $\begin{array}{l}\text { Wholegrain, containing fiber, polyphenols, } \\
\text { fatty, and amino acids } \\
\text { - Buckwheat } \\
\text { - Millet } \\
\text { - Rye bread } \\
\text { - Brown rice } \\
\text { - Purple rice }\end{array}$ & $\begin{array}{l}\text { Aromatase } \\
\text { Nuclear receptor } \\
\text { VEGF receptor } \\
\text { COX-2 }\end{array}$ & - \\
\hline
\end{tabular}

For references see text.

- Buckwheat, millet, or brown and purple rice

- Cabbage, broccoli, cauliflower, kale, and bock choy

- Garlic and tomatoes as a result of indole-3 carbinol and carotinoid (lycopin) content

- Mangosteen, grapefruits, and other citrus fruits as a result of monoterpenes content

- Grapeseed due to procyanidin B dimer and resveratrol

- Pomegranates due to ellagitannins (the most potent being urolithin B)

- And mushrooms (white button, baby button, shiitake, portobello, and crimini) due to conjugated linoleic acid.

Induction of aromatase and thus increase of breast cancer risk can be associated with ethanol. Liquorice (glycyrrhizin from 
glycyrrhiza glabra) reduces serum testosterone and induces ovulation by induction of aromatase (85-90).

Various flavonoids have been tested and the effect been quantified on cell lines only, but not in vivo (e.g., H295R adrenocortical carcinoma cells). Chalcones and flavanones such as naringenin and hesperetin, flavones such as rotenone or luteolin, catechins such as theaflavin or stilbenoids such as resveratrol are stronger than other flavonoid derivatives (81, 91-94). Prophylaxis of breast cancer by flavonoid intake depends on the amounts consumed. Also, a proteinrich diet including $300 \mathrm{~g}$ soy protein corresponds to more than $100 \mathrm{~g}$ isoflavones per day is having an effect in breast cancer prevention. Although the potency of isoflavones is a mere permille of physiological $17 \beta$-estradiol, it may significantly modulate estradiol effects at the estradiol receptors due to its high affinity for the $\alpha$-receptor subtype, inducing a competitive inhibition in this way. The relative concentrations of estradiol and of isoflavones competing for the receptor will determine the long-term prophylactic success (95).

Some authors describe more precisely the presumed mechanism of action of active ingredients. Purple rice extract inhibit VEGF (vascular endothelial growth factor)-induced angiogenesis at the cell surface receptor (96). Organosulfur compounds from garlic and other allium species are able to suppress cancer cell proliferation by inhibiting the cell division cycle of phosphatases rather than aromatase (97). 36 ß-caryophyllene oxide's target is the cell signaling cascade. Cell growth is inhibited and apoptosis induced by the suppression of PI3K (phosphatidylinositol 3 kinase) pathways and ROS (reactive oxygen species)-mediated MAPKs (mitogen-activated protein kinases) activation (98).

A further explanation for the inhibiting effect of flavonoids on aromatase is the inhibition of activity and expression of histone deacetylation. As acetylated histones widen DNA and therefore favor transcription, this mechanism corresponds to a procedure of switching genes on. Acetylation opens chromatin and enables transcription. Therefore, inhibition of acetylation might limit DNA replication in tumor tissues, an important regulation of repressing cancer genes. Switching off genes would be accomplished by silent (condensed) chromatin, enhanced by methylation of cytosines and deacetylation of histones. These switching genes on/switching genes off mechanisms are highly important for epigenetic labeling and adaption to changing environmental conditions (99-101).

Epigenetics also seem to play an important role in these interindividual differences. A study with 300'000 recruits from the Dutch army showed that famine has a statistically significant influence and that a fetal memory exists. Malnutrition during the first trimester of pregnancy experienced by the mothers of these recruits in 1944-45 ("hunger winter") led to an elevated rate of obesity of their sons by the age of 19 . The cause was a modification of methylation on the IGF2 gene which promotes growth during pregnancy (102-104).

Traditional antioxidation diet is one of the most approved explanation of inhibition of aromatase by phytonutrients of flavonoid derivatives. However, this means as well that flavonoids compete for the oxygen in the course of enzymatic oxidoreduction, and therefore of aromatase-catalyzed conversion of steroid precursors to estrogens.

\section{Resveratrol}

From resveratrol the two enantiomeres trans-(E)-resveratrol and cis-(Z)-resveratrol exist. Due to the (E)-enantiomere's stilbenoid structure resembling to a partial structure of $\alpha, \beta$ unsaturated ketone of the steroid's ring A, aromatase is inhibited competitively by resveratrol (Figure 6). The trans-isomer is more stable. Trans to cis somerization is facilitated by UV light of $200-400 \mathrm{~nm}$ and high $\mathrm{pH}$. Cis to trans conversion is facilitated by visible light of $400-800 \mathrm{~nm}$, high temperature, and low $\mathrm{pH}$. Roasting has a diminishing effect on polyphenolic composition and antioxidant activity. Sources of resveratrol comprise (105-113):

- Fresh grape skin: $50-100 \mu \mathrm{g} / \mathrm{g}$

- Red wine: $(98-1,803 \mu \mathrm{g} / \mathrm{g}$ cis-resveratrol, $0.5-26 \mu \mathrm{g} / \mathrm{g}$ transresveratrol)

- Peanuts skin: $0.02-1.79 \mu \mathrm{g} / \mathrm{g}$

- Strawberry: $0.83 \mu \mathrm{g} / \mathrm{g}$

- Hop: 0.23-2.28 $\mu \mathrm{g} / \mathrm{g}$

- Common buckwheat: 0.98-1.68 $\mu \mathrm{g} / \mathrm{g}$

- Tartary buckwheat: 3.43-3.5 $\mu \mathrm{g} / \mathrm{g}$.

\section{Nutrigenomics and Further OMICS Technologies}

The human body encodes approximately 50 members of nuclear hormone receptors on the DNA, consisting of DNA-binding and ligand binding domains. A number of cysteine residues binds zinc ions to stabilize the structure of these zinc-finger domains of steroid receptors. The impact of mutations on the genetic coding, currently known as single nucleotide polymorphisms (SNPs), is a key issue to prevent mistranscription and mistranslation (e.g., "the sun is now red" $\neq$ "the sun is not red"). Genomics, transcriptomics, proteomics, metabolomics, and other omics technologies have been identified as key technologies to find answers to unresolved questions such as to why individuals respond differently to equal bioactives ${ }^{1}$. During aromatase and SERM treatment, "either de novo or acquired resistance is seen with many patients. With de novo resistance, due to reduced influence of estrogen receptors (ER) activity in these types of tumors, there is no response to a drug upon initial treatment. Furthermore, some patients acquire resistance after initially responding to a drug treatment while still maintaining ER expression. This strongly suggests that ER may still play an important role after acquiring resistance to anti-hormonal drugs has developed." Reasons for resistance comprise (77):

- Mutations and/or variants of estrogen receptors and of aromatase

- Modifications of the apoprotein of aromatase in its posttranscriptional or post-translational biosynthesis

- SNPs of enzymes involved in aromatase's prosthetic group biosynthesis, i.e., heme biosynthesis

- Modifications in the cell-signaling pathways triggered by docking substrates at the estrogen receptor. 
Endocrine resistance is not yet fully understood. More research is needed in order to develop target specific drugs not affected by endocrine resistance. Apart from inborn errors in direct biosynthesis pathways, the all enzymes involved in the underlying biosynthesis pathways (up to multiple levels upstream) such as the porphyrin biosynthesis are important elements of an overall functioning metabolism. The ALA-synthetase catalyzed formation of $\delta$-aminolevulinic acid, starting from succinate and glycine, is the first and rate-limiting step of heme biosynthesis. There is a particular role of the vitamin b12-tetrahydrofolatemethionine/homocysteine system as carriers of methyl bricks. The need of these carriers for heme biosynthesis explains why not every anemia is an iron anemia and therefore cannot be treated by iron supplementation. It may be diagnosed as pernicious anemia due to a vitamin b12 deficiency. Iron is only the last piece introduced as central atom and cofactor to the heme moiety (114). The same as for porphyrin biosynthesis is applicable for steroid biosynthesis via cholesterol. This biochemical pathway starts from various sources such as glycolysis or beta-oxidation bringing up AcCoA bricks. Assembling these $\mathrm{C} 2$ units up to cholesterol is rate-limited by the HMG-CoA-reductase step. Even the arborization to the sexual steroids starting from cholesterol and progesterone involves more than 30 enzymes in the biosynthesis of $17 \beta$-estradiol. The whole system is highly regulated and equilibrated (115). A single inborn error in a relevant biosynthetic step may dramatically change this equilibrium. To diagnose an inborn error in the steroid metabolism would need first the identification of genes associated with the disease, commonly assumed by consortia research. The whole genomes of participants with a disease and healthy people need to be sequenced and plotted in a Manhattan plot depicting the abundancy of SNPs (y-axis) against all chromosomes (x-axis). The most abundant SNPs are likely to include the genes responsible for a disease.

Omics technologies include genomics, transcriptomics, proteomics, metabolomics, and many more. Neglecting genes and their impact on phenotypes bears a high risk for biases or confounding for study outcomes. Genetic heterogeneity must therefore be included in clinical trials to omit type II errors arising from unequal randomization to study groups. For example, a new drug presumed to be more potent than a Gold Standard cannot be recognized in a clinical trial in case the treatment group counts more fast metabolizers compared to the control group (Figure 7).

Most of the genomic DNA sequence differences between any two people are common single nucleotide polymorphisms (SNPs) with a minor allele frequency of more than $5 \%$ as related to the wild type. The common disease-common variant hypothesis expresses the fact of genetic risk as being due to common SNPs (116). Very rare allele frequency may have a high effect size. They cause Mendeleian diseases of high interest for prenatal medical genetic screening, e.g., phenylketonuria, cystic fibrosis. The penetration of this disease is complete. A mutated gene causes the disease. On the other hand, common allele frequencies with high effects on common diseases are rare. Their penetration is only partial, i.e., an allele is not necessarily determining a disease. Such polymorphisms are neutral or only mildly harmful with respect to survival of a person or of a species as long as alternative metabolic pathways permit bypassing rate-limiting and committed enzymatic reactions. In the band between evolutionary pressure and statistical power are included high effect sizes for rare diseases, low-frequency variants with intermediate effects, and common variants implicated in common diseases. There are many non-communicable diseases in oncology (with some 114 predisposing genes known), psychiatry, obesity, or type 2 diabetes mellitus which can be associated with lifestyle. Rare variants of small effects are difficult to be identified by genetic means, and only rare examples are known for high-effect common variants causing common diseases (117).

Whereas, genome-wide associations can detect reliably genes of Mendeleian inherited disease, it is more complex for syndromes with a polygenic risk. Many of the associated genes with such diseases such as obesity are not causal but only tagging a causal marker. After many generations, tags disappear, the disease-causing alleles persist, a phenomenon known as linkage disequilibrium. Consortia activities contribute most to the increasing knowledge about these diseases. Results cannot simply be transferred to all populations because European ancestry is overrepresented as compared to the global population (118). Another shortcoming of GWAS studies is their statistical character. The higher a sample size, the more significant hits will result. First attempts efforts to associate genes with psychiatric diseases were not successful. In 2009, with 2,601 cases with no hits were detected whereas with 36,000 cases in 2014, 108 hits resulted (119).

As far as ethnicity, the Indian subcontinent shows high incidence cardio-vascular diseases causing four times higher risks of heart attack before the age of 50 and high death rates in 1 of 3 persons fading away before the age of 65 . In this population group, high gestational diabetes and metabolic syndrome rates are encountered more often than in any other ethnicity. These diseases are obviously caused by a set of many single nucleotide polymorphisms (SNPs) and thus bear a polygenetic risk arising among others from genes coding for interleukin-6 (IL6), methylenetetrahydrofolate reductase (MTHFR), intercellular adhesion molecule (ICAM-1), a membrane protein stimulated by retinoic acid (STRA6), or retinol binding protein 4 (RBP4) (120).

\section{DISCUSSION}

\section{The Relevance of Nutrigenomics and Further OMICS Technologies}

As depicted repeatedly above, nutrigenomics becomes relevant for the interpretation of antitumoral effects and further interactions of foodstuff with genes, for potential errors encountered in clinical studies without genomic testings performed on the study population, or in public health as related to non-communicable diseases. Genes code both for metabolismrelevant enzymes and for receptors or targets of medicines and nutrients.

Looking at a person's family roots, it is of interest for both the individual and researcher to know the risks for 
A
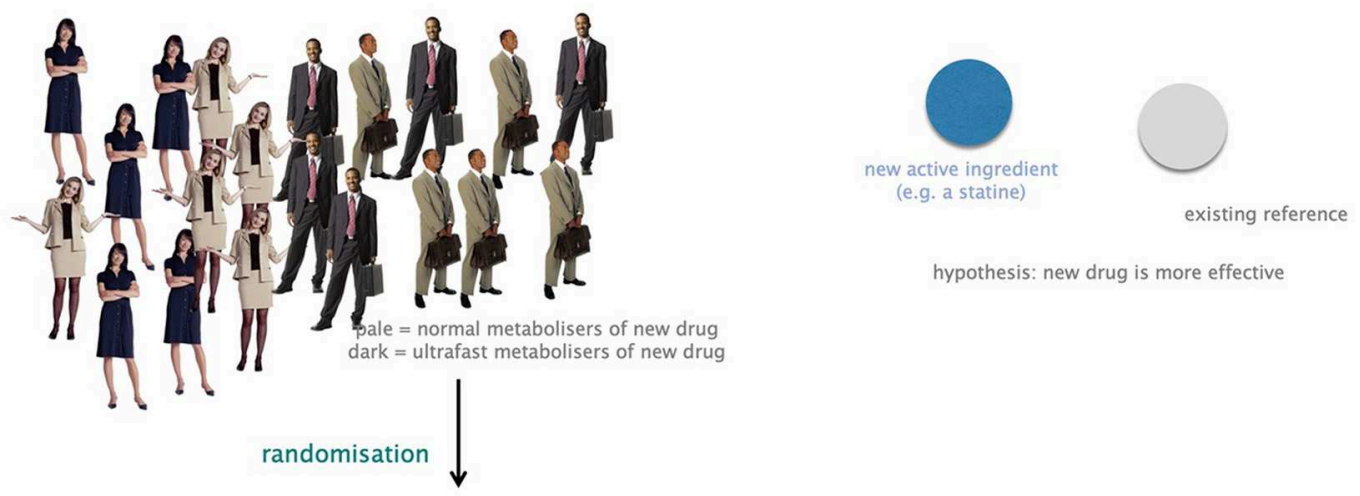

Treatment group
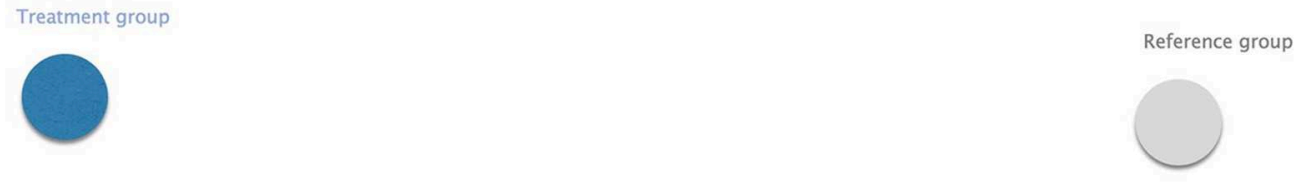

B
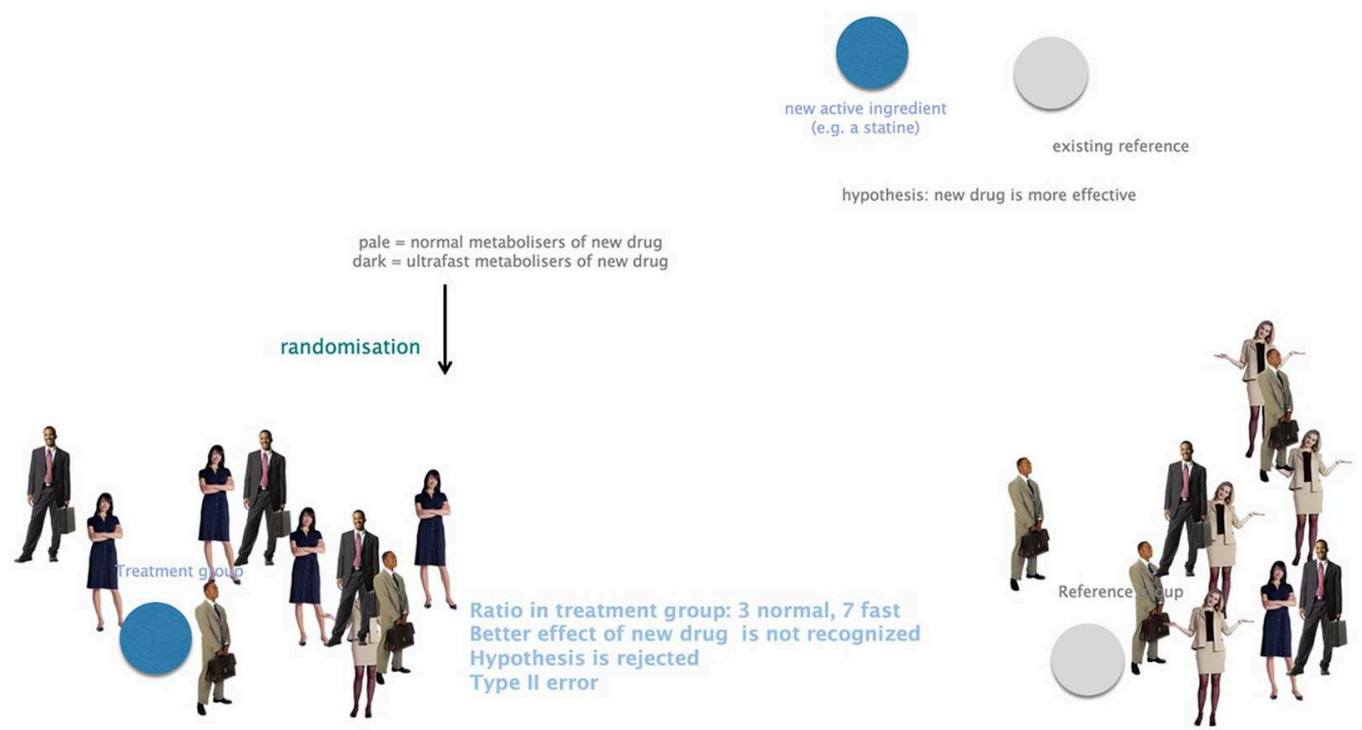

FIGURE 7 | The importance of considering genetic heterogeneity and individual requirements in research and therapy. (A) A group of study participants with equally frequent fast and normal metabolizers. (B) Small study groups might suffer from unequally distributed fast and normal metabolizers. A presumably more potent new drug could not be recognized in this case. This leads to bias and confounding due to negligence of genetic profiling. Example: the ratio in the treatment group is 3 normal and 7 fast metabolizers. The better effect of the new drug is not recognized. The hypothesis that the new drug is more potent would be rejected. This is a type II error.

developing obesity in later life. Obesity is an epidemy worldwide and associated with many health problems, amongst others diabetes, cardiovascular diseases, and cancer. There is a clear (epi)genetic component to a predisposition to obesity. In the last decade, genome-wide studies analyzed hundreds of thousands of SNPs (single nucleotide polymorphisms) and led to a better understanding of the genetic causes of obesity. By 2012, 40 locis were described and associated with obesity and BMI (body mass index). So, slim father and obese mother, or the other way around, whose alleles are found in the siblings? Among at least 65 relevant 
enzyme's determining energy metabolism, which ones are coding for deficiencies leading to inborn errors associated with obesity albeit in the carbohydrate (glycolysis) or in the lipid metabolism (beta-oxidation) or in in the energy production (citric acid cycle, respiratory chain). The impact of nutrigenomics might be a suitable motivation for nutrition researchers to override some decades of very modest concrete results output and recognize precise relationships between nutritional behavior and disease. Patients suffering worldwide from obesity are waiting for explanations regarding why they are concerned by this disease.

Public health and one-fits-all approaches in nutrition do not satisfy requirements of therapeutic precision in times of personalized nutrition. Physiological and biochemical processes in vivo are the result of an individual metabolism which is expressed as encoded by its genes. The individualized capacity of metabolism is affecting qualitative and quantitative uptake of nutrients and xenobiotics in the pharmaco- and nutrientkinetics steps even before a substrate has found its target. It is continued when the substrate is binding to the fitting physiological receptor. Due to the genetic code this one can be configured qualitatively and quantitatively in a different way than in another person. Nutrigenomics is therefore an emerging research topic to support medical genetics and modern cell and gene therapy of diseases such as spinal atrophy, sickle-cell anemia, many inherited oncological diseases. Whereas, testing a SNP is easy and routine meanwhile, coping with polygenic risks will remain a challenge for the next decades.

What has been widely practiced in pharmacotherapy is urgently needed to be applied in nutritional sciences. Traditional nutrition research did not succeed to put out breakthroughs in the past decades. Epidemiological and qualitative questionnairesdominated methodologies suffered from serious biases and confounding. Generalizations to whole populations were made although results were just applicable for a defined study population and regional behaviors.

\section{Summary of Main Findings}

Public health dominated research is more and more competed by personalized research approaches. The mystery of biochemical pathways applies commonalities as long as the mechanisms and principles of anabolism and catabolism are in the focus. On a quantitative level however, a person's metabolic capacity depends on his or her individual genetic pattern.

Absorption of nutrients and xenobiotics is mainly an individualized procedure depending on a human being's metabolic capacity. This in turn varies with age, gender, ethnicity, and inherited metabolic performance. It is gender-, age-, and ethnic-dependent whether an individuum can be attributed to a certain group of metabolizers. Depending on the age and gender, the ratios of body compartments vary and therefore the distribution according to the hydrophilic-lipophilic profile of a substrate. Metabolism is discussed mainly in terms of the hepatic part due to its predominance, although it happens also in extra hepatic hormone-dependent tissues. The role of CYP450 isoenzymes is a central and determining one as it does not only act as monooxygenase to detoxify but also to biosynthesize from metabolites further hormonal active substances such as estrogens. The mechanisms of action and the catalytic cycles themselves depend on further enzymes, which are themselves highly regulated. Excretion is often discussed as an isolated procedure. However, the Bateman function describing the course of plasma level is in fact the sum of absorption, distribution, metabolism, and excretion.

On a pharmaco- and nutrient-dynamic level, aromatase as central interest of this review and target of the precursors of estrogens is also a main target of medicines used in breast cancer treatment. Nutrients of the flavonoid group are partially structurally similar to estradiol precursors testosterone and androstendione. They have a relevant potential to prevent breast cancer and to be used as adjuvants in pharmacotherapy.

Knowing biochemistry of pharmacokinetics (LADME) and pharmacodynamics as well as biosynthesis of the main carriers and enzymes of these procedures is not enough. As the metabolic capacity of a person is depending on the genome and various circumstances relevant for the expression of these genes, noncommunicable diseases cannot be prevented in the population by treating specific pathways without considering genetics and epigenetics.

Genetic regulation of metabolism is a complex procedure affecting multiple pathways. All ATP-dependent metabolic steps need an effective glycolysis (for pyruvate and acetylCoA production), citric acid cycle (for electron harvesting), and respiratory chain/oxidative phosphorylation (for ATP replenishment). Fine-tuning this kind of energy production depends therefore on co-enzymes (B-vitamins) and co-factors (mainly iron, copper). Energy production in combination to gene regulation by "anti-oxidant" nutrients are key elements for cancer prevention and add-on therapies parallel to conventional cytotoxic protocols.

In most of the cases, to obtain an entirely well-resolved picture of a pathogenic situation, there is a need to know underlying biochemical pathways. Therefore, an inborn error of metabolism ending up in manifest breast tumor needs to be assessed within the affected tissue, the involved physiological substrates and metabolites, the capacity of enzymes involved in these steps, the capacity of underlying biochemical pathways, and finally the genotype and phenotype of the patient. It may even be wise to evaluate environmental circumstances, epigenetics, and immunological enhancers or inhibitors.

With the infinite number of recombination of the genes, each person is unique, and all diagnosis must consider the genetic patterns with numbers of SNPs leading to differences in liberation, absorption, distribution, metabolism, and excretion of nutrients from a food matrix. A variable uptake of bioactives is the first quantitative difference in nutritional therapy. Receptors of any two persons may differ in their number and in their structure. These differences potentiate the quantitative differences of a response to nutrients intake.

\section{Limitations}

Although scientific publications have been carefully selected, not all are arising from evidence-based findings of clinical trials. Some interpretations and statements are based on biochemically and pharmaceutically accepted theories and state of the art. 
Commonalities and principles have been proved over centuries. Evidence can only be generated if methodologies are convincing. However, many publications are limited to regional or ethnical frames and cannot be transferred to other ethnicities. And many studies are erroneous, because genetic profiling has been neglected. It is preferable to interpret and reevaluate carefully some findings from early publications as soon as new knowledge is emerging on a novel research field. Often, early findings remain standards although new insight hints at pitfalls in methodologies.

The statements made in this article might be countered in later research activities.

\section{CONCLUSION}

Nutrition science needs to consider the genome of an individual to truly find answers to nutrition-derived non-communicable diseases. All steps from intake to effect are genetically encoded. Genetic tests to detect risks for pathologies and determine optimal individual diets should be considered in nutrition research and practices. With current GWAS approaches, inherited errors of metabolism are identified and ideally treated effectively as long as the one variant-one disease hypothesis is applicable. It is much more difficult to get a precise genetic profile for multifactorially caused non-communicable diseases. Polygenic risks are feasible but diagnostic tools are not yet available in a desired extent. As to whether explanations beyond pure chemical mechanisms of action are described in the

\section{REFERENCES}

1. Zimmer P. RF. Available online at: https://www.rogerfederer.com/index.php (accessed Jun 24, 2019).

2. Reader's Digest Best Health. Girlfriend's Guide - 10 Foods that Fight Breast Cancer. Available online at: https://www.besthealthmag.ca/bestyou/girlfriends-guide/10-foods-that-fight-breast-cancer/ (accessed Jun 19, 2019).

3. NN. Food for Breast Cancer. Available online at: https://foodforbreastcancer. com/amp (accessed Jun 12, 2012).

4. Ioannidis JPA. The challenge of reforming nutritional epidemiologic research. JAMA. (2018). 320:969-70. doi: 10.1001/jama.2018. 11025

5. SGE. Swiss Food Pyramid. Available online at: http://www.sge-ssn.ch/media/ sge_pyramid_E__basic_20161.pdf (accessed Jun 24, 2019).

6. SGE. DACH-Referenzwerte. Available online at: http://www.sge-ssn. ch/grundlagen/lebensmittel-und-naehrstoffe/naehrstoffempfehlungen/ dachreferenzwerte/ (accessed February 28, 2019).

7. Ioannidis JPA. Implausible results in human nutrition research. BMJ. (2013) 347:f6698. doi: 10.1136/bmj.f6698

8. Estruch R, Ros E, Salas-Salvadó J, Covas MI, Corella D, Arós F, et al. Primary prevention of cardiovascular disease with a Mediterranean diet supplemented with extra-virgin olive oil or nuts. N Engl J Med. (2018) 378:e34. doi: 10.1056/NEJMoa1800389

9. PRISMA. Prisma-Statement. (2018). Available online at: http://prismastatement.org/ (accessed March 8, 2018).

10. Mayer JM, Balant LP. Der pharmakokinetische Kubus - Das Werden des Medikaments im Körper (CD - ROM v1.1). ASTRAL collection PROGRESS (2001). literature, the answer is that neither authors, nor providers of genetic testing kits are going into the details needed for a truly personalized nutritional medicine. The next step with sequencing the whole exome is on the threshold of becoming routine diagnosis. The further step of sequencing the entire genome will bring the desired details such as regulation option by introncoded miRNA and further nucleic acid or protein fragments. On this way, actual genetic testing is only an intermediate sojourn on the way to whole genome sequencing.

\section{DATA AVAILABILITY STATEMENT}

The raw data supporting the conclusions of this article will be made available by the authors, without undue reservation, to any qualified researcher.

\section{AUTHOR CONTRIBUTIONS}

HJ and LS-R contributed equally to the general nutritional medical contents and nutrigenomics. HJ lead the paragraphs oriented to clinical nutritional therapy, biochemistry, and mechanisms of action. LS-R lead the paragraphs on biology and public health nutrition.

\section{FUNDING}

This work was funded by an internal grant of Bern University of Applied Sciences (BFH-Nr.: 14165DPT_WGS).
11. Asha S, Vidyavathi M. Role of human liver microsomes in in vitro metabolism of drugs-a review. Appl Biochem Biotechnol. (2009) 160:1699722. doi: 10.1007/s12010-009-8689-6

12. Storka A, Pleiner J. Medikamenteninteraktionen in der Gastroenterologie. J Gastroenterol Hepatol Erkr. (2008) 6:21-5.

13. Jenzer H, Müller S, Sadeghi L. CYP450 isoenzyme-associated food-drug interactions are a neglected issue in medicines information. EJHP. (2015) 22(Suppl. 1):A136-7.

14. Subbiah MTR. Nutrigenetics and nutraceuticals: the next wave riding on personalized medicine. Transl Res. (2007)149:5561. doi: 10.1016/j.trsl.2006.09.003

15. Ordovas JM. Genotype-phenotype associations: modulation by diet and obesity. Obesity. (2008) 16:S40-6. doi: 10.1038/oby.2008.515

16. Fenech M. Genome health nutrigenomics and nutrigenetics - diagnosis and nutritional treatment of genome damage on an individual basis. Food Chem Toxicol. (2008) 46:1365-70. doi: 10.1016/j.fct.2007.06.035

17. Penders B. Personalised diet: is it doable? Individuality at different sites of nutrigenomic practice. Genes Nutr. (2007) 2:93-4. doi: 10.1007/s12263-007-0021-x

18. Ghosh D, Skinner MA, Laing WA. Pharmacogenomics and nutrigenomics: synergies and differences. Eur J Clin Nutr. (2007) 61:567-7. doi: 10.1038/sj.ejcn. 1602590

19. Chadwick R. Nutrigenomics, individualism and public health. Proc Nutr Soc. (2004) 63:161-66. doi: 10.1079/PNS2003329

20. Muller M, Kersten S. Nutrigenomics: goals and strategies. Nat Rev Genet. (2003) 4:315-22. doi: 10.1038/nrg1047

21. Naylor S, Chen J. Unraveling human complexity and disease with systems biology and personalized medicine. Personal Med. (2000) 7:27589. doi: $10.2217 /$ pme.10.16 
22. Kaput J, Perlina A, Hatipoglu B, Bartholomew A, Nikolsky Y. Nutrigenomics: concepts and applications to pharmacogenomics and clinical medicine. Pharmacogenomics. (2007) 8:369-90. doi: 10.2217/14622416.8.4.369

23. Fenech M, El-Sohemy A, Cahill L, Ferguson LR, French TA, Tai ES, et al. Nutrigenetics and nutrigenomics: viewpoints on the current status and applications in nutrition research and practice. J Nutrigenet Nutrigenomics. (2011) 4:69-89. doi: 10.1159/000327772

24. Jenzer H, Denkel C, Kopf-Bolanz KA, Büsser S, Birrer J, Müller S, et al. Aromatase inhibitors in food - processing matters. Aktuell Ernahrungsmed. (2015) 40:179-80. doi: 10.1055/s-0035-1550164

25. Freire AC, Basit AW, Choudhary R, Piong CW, Merchant HA. Does sex matter? The influence of gender on gastrointestinal physiology and drug delivery. Int J Pharm. (2011) 415:15-28. doi: 10.1016/j.ijpharm.2011. 04.069

26. Lahner E, Annibale B, Delle Fave G. Systematic review: impaired drug absorption related to the co-administration of antisecretory therapy. Aliment Pharmacol Ther. (2009) 29:1219-29. doi: 10.1111/j.1365-2036.2009.03993.x

27. Henry EB, Carswell A, Wirz A, Fyffe V, McColl KEL. Proton pump inhibitors reduce the bioavailability of dietary vitamin C. Aliment Pharmacol Ther. (2005) 22:539-45. doi: 10.1111/j.1365-2036.2005.02568.x

28. Hutchinson C, Geissler CA, Powell JJ, Bomford A. Proton pump inhibitors suppress absorption of dietary non-haem iron in hereditary haemochromatosis. Gut. (2007) 56:1291-95. doi: 10.1136/gut.2006.108613

29. Ogawa R, Echizen H. Drug-drug interaction profiles of proton pump inhibitors. Clin Pharmacokinet. 49:50933. doi: 10.2165/11531320-000000000-00000

30. Howden CW. Vitamin B12 levels during prolonged treatment with proton pump inhibitors. J Clin Gastroenterol. (2000) 30:29-33. doi: 10.1097/00004836-200001000-00006

31. Fournier MR, Targownik LE, Leslie WD. Proton pump inhibitors, osteoporosis, and osteoporosis-related fractures. Maturitas. (2009) 64:913. doi: 10.1016/j.maturitas.2009.07.006

32. Jenzer H, Marty I, Büsser S, Silva M, Scheidegger-Balmer F, Ruch LJ, et al. Know-how and know-why nutrients may be less bioaccessible and less bioavailable due to proton pump inhibitor - food interactions and incompatibilities involving metal-aquo complexes. J Nutr Disorders Ther. (2016) 6:191-9. doi: 10.4172/2161-0509.1000191

33. Netzer P, Brabetz-Höfliger A, Bründler R, Flogerzi B, Hüsler J, Halter F. Comparison of the effect of the antacid Rennie versus low-dose H2receptor antagonists (ranitidine, famotidine) on intragastric acidity. Aliment Pharmacol Ther. (1998). 12:337-42. doi: 10.1046/j.1365-2036.1998.00316.x

34. Wilder-Smith $\mathrm{CH}$, Bondarov $\mathrm{P}$, Lundgren $\mathrm{M}$, Niazi $\mathrm{M}$, Röhss $\mathrm{K}$, Ahlbom $\mathrm{H}$, et al. Intravenous esomeprazole $(40 \mathrm{mg}$ and $20 \mathrm{mg}$ ) inhibits gastric acid secretion as effectively as oral esomeprazole: results of two randomized clinical studies. Eur J Gastroenterol Hepatol. (2005) 17:19197. doi: 10.1097/00042737-200502000-00010

35. Röhss K, Lind T, Wilder-Smith C. Esomeprazole $40 \mathrm{mg}$ provides more effective intragastric acid control than lansoprazole $30 \mathrm{mg}$, omeprazole $20 \mathrm{mg}$, pantoprazole $40 \mathrm{mg}$ and rabeprazole $20 \mathrm{mg}$ in patients with gastrooesophageal reflux symptoms. Eur J Clin Pharmacol. (2004) 60:53139. doi: 10.1007/s00228-004-0804-6

36. Stedman CAM, Barclay ML. Review article: comparison of the pharmacokinetics, acid suppression and efficacy of proton pump inhibitors. Aliment Pharmacol Ther. (2000) 14:96378. doi: 10.1046/j.1365-2036.2000.00788.x

37. AstraZeneca. Nexium - Esomeprazole EAHP Fragebogen zur Information von Krankenhausapothekern über das Fertigarzneimittel. Version 8 (2010), Baar.

38. Documed. Arzneimittelkompendium der Schweiz $\AA$ - Nexium $®$. In: Documed, editor (2011). Available online at: http://www.compendium.ch/ Search (accessed July 14, 2019).

39. Pali-Schöll I, Jensen-Jarolim E. Anti-acid medication as a risk factor for food allergy. Allergy. (2011) 66:469-77. doi: 10.1111/j.1398-9995.2010.02511.x

40. Sandvik AK, Waldum HL, Brenna E. Long-term safety of proton pump inhibitors: risks of gastric neoplasia and infections. Expert Opin Drug Safety. (2002) 1:29-38. doi: 10.1517/14740338.1.1.29

41. Untersmayr E, Jensen-Jarolim E. The role of protein digestibility and antacids on food allergy outcomes. J Allergy Clin Immunol. (2008) 121:130108. doi: 10.1016/j.jaci.2008.04.025
42. Dunn BE, Campbell GP, Perez-Perez GI, Blaser MJ. Purification and characterization of urease from Helicobacter pylori. J Biol Chem. (1990) 265:9464-69.

43. Jensen-Jarolim E, Untersmayr E. Gender-medicine aspects in allergology. Allergy. (2008) 63:610-15. doi: 10.1111/j.1398-9995.2008.01645.x

44. Teramura-Groenblad M, Hosia-Randell H, Muurinen S, Pitkala K. Use of proton-pump inhibitors and their associated risks among frail elderly nursing home residents. Scandinav J Prim Health Care. (2010) 28:15459. doi: $10.3109 / 02813432.2010 .493315$

45. Tursi A. The treatment of gastro-esophageal reflux disease in adult celiac disease. J Clin Gastroenterol. (2004) 38:724-26. doi: 10.1097/01.mcg.0000135373.879 $74.3 \mathrm{~d}$

46. Mehta N, Saha S, Chien EKS, Esposti SD, Segal S. Disorders of the gastrointestinal tract in pregnancy. In: De Swiet's Medical Disorders in Obstetric Practice. Chichester: Wiley-Blackwell (2010). p. 256-92. doi: 10.1002/9781444323016.ch10

47. Jolivet JP, Chanéac C, Tronc E. Iron oxide chemistry. From molecular clusters to extended solid networks. Chem Commun. (2004) 2004:4817. doi: 10.1002/chin.200418249

48. Crichton R. Solution chemistry of iron in biological media. In: Iron Metabolism-From Molecular Mechanisms to Clinical Consequences. 3rd ed. Chichester: Wiley (2009). p. 1-461. doi: 10.1002/9780470010303

49. Jenzer H, Krummenacher M, Beyeler M, Sadeghi L. Proton pump inhibitor induced malabsorption of transition metals whith co-factor function: simulation of the impact of raising gastrointestinal pH. EJHP. (2017) 24(Suppl. 1):A199. doi: 10.1136/ejhpharm-2017-000640.442

50. Klinger W. Developmental pharmacology and toxicology: biotransformation of drugs and other xenobiotics during postnatal development. Eur J Drug Metab Pharmacokinet. (2005) 30:3-17. doi: 10.1007/BF03226403

51. Ebers DW, Smith DI, Gibbs GE. Gastric acidity on the first day of life. Pediatrics. (1956) 18:800-2.

52. Miller R. Observations on the gastric acidity during the first month of life. Arch Dis Child. (1941) 16:22-30. doi: 10.1136/adc.16.85.22

53. Boyle JT. Acid secretion from Birth to adulthood. J Pediat Gastroenterol Nutr. (2003) 37:S12-6. doi: 10.1097/00005176-200311001-00004

54. Deren JS. Development of structure and function in the fetal and newborn stomach. Am J Clin Nutr. (1971) 24:144-59. doi: 10.1093/ajcn/24.1.144

55. Sondheimer JM, Clark DA, Gervaise EP. Continuous gastric pH measurement in young and older healthy preterm infants receiving formula and clear liquid feedings. J Pediatr Gastroenterol Nutr. (1985) 4:352-55. doi: 10.1097/00005176-198506000-00005

56. Maffei HV, Nóbrega FJ. Gastric pH and microflora of normal and diarrhoeic infants. Gut. (1975) 16:719-26. doi: 10.1136/gut.16.9.719

57. Woodhead JC, Drulis JM, Nelson SE, Janghorbani M, Fomon SJ. Genderrelated differences in iron absorption by preadolescent children. Pediatr Res. (1991) 29:435-39. doi: 10.1203/00006450-199105010-00005

58. Stute P, Kiesel L. Molekulare Endokrinologie. Gynäkologische Endokrinologie. (2006) 4:154-60. doi: 10.1007/s10304-006-0150-0

59. Johnson PE, Milne DB, Lykken GI. Effects of age and sex on copper absorption, biological half-life, and status in humans. Am J Clin Nutr. (1992) 56:917-25. doi: 10.1093/ajcn/56.5.917

60. Edelman AB, Cherala G, Stanczyk FZ. Metabolism and pharmacokinetics of contraceptive steroids in obese women: a review. Contraception. (2010) 82:314-23. doi: 10.1016/j.contraception.2010.04.016

61. Westhoff CL, Torgal AH, Mayeda ER, Pike MC, Stanczyk FZ. Pharmacokinetics of a combined oral contraceptive in obese and normal-weight women. Contraception. (2010) 81:47480. doi: 10.1016/j.contraception.2010.01.016

62. Richter JE. Review article: the management of heartburn in pregnancy. Aliment Pharmacol Ther. (2005) 22:74957. doi: 10.1111/j.1365-2036.2005.02654.x

63. Dehlink E, Yen E, Leichtner AM, Hait EJ, Fiebiger E. First evidence of a possible association between gastric acid suppression during pregnancy and childhood asthma: a population-based register study. Clin Exp Allergy. (2009) 39:246-53. doi: 10.1111/j.1365-2222.2008.03125.x

64. Flockhart DA. Drug Interactions: Cytochrome P450 Drug Interaction Table. Indiana University School of Medicine (2018) Available online 
at: http://medicine.iupui.edu/clinpharm/ddis/main-table/ (accessed March $8,2018)$.

65. Jenzer H. Molecular mechanisms and side reactions of thyroid hormone biosynthesis Inaugural Dissertation submitted for the degree of Doctor of Pharmacy in the Faculty of Medicine of the University of Bern, Bern, Switzerland (1987).

66. Lewis DFV, Ito Y, Goldfarb PS. Cytochrome P450 structures and their substrate interactions. Drug Dev Res. (2005) 66:1924. doi: $10.1002 / \mathrm{ddr} .20040$

67. Poulos TL, Johnson EF. Structures of cytochrome P450 enzymes. In: Ortiz de Montellano PR, editor. Cytochrome P450, Structure, Mechanism, and Biochemistry, 4th ed. Cham: Springer (2015). p. 3-32. doi: 10.1007/978-3-319-12108-6_1

68. Berg JM, Tymoczko JL, Stryer L. Biochemistry. 5th ed. New York, NY: Freeman (2002)

69. Jenzer $\mathrm{H}$, Jones $\mathrm{W}$, Kohler $\mathrm{H}$. On the molecular mechanism of lactoperoxidase-catalyzed $\mathrm{H}_{2} \mathrm{O}_{2}$ metabolism and irreversible enzyme inactivation. J Biol Chem. (1986) 261:155506. doi: 10.1016/S0006-291X(86)80117-6

70. Richfield D. The P450 Catalytic Cycle (MSc thesis) (2008) Available online at: https://en.wikipedia.org/wiki/File:P450cycle.svg (accessed August 17, 2011).

71. Lelong H, Galan P, Kesse-Guyot E, Fezeu L, Hercberg S, Blacher J. Relationship between nutrition and blood pressure. Am J Hypertens. (2015) 28:362-71. doi: 10.1093/ajh/hpu164

72. Moore LL, Singer MR, Bradlee ML. Low sodium intakes are not associated with lower blood pressure levels among Framingham offspring study adults. FASEB J. (2017) 31:abstract 446.

73. He FJ, Macgregor GA. Effect of longer-term modest salt reduction. Cochrane Database Syst Rev. (2013) 4:CD004937. doi: 10.1002/14651858.CD004937.pub2

74. Alderman MH. Salt, blood pressure and health - a cautionary tale. Am J Hyperten. (2015) 28:362-71. doi: 10.1093/ije/31.2.311

75. Ortiz de Montellano PR. Substrate oxidation by cytochrome P450 enzymes. In: Ortiz de Montellano PR, editor. Cytochrome P450, Structure, Mechanism, and Biochemistry. 4th ed. Cham: Springer (2015). p. 111176. doi: 10.1007/978-3-319-12108-6_4

76. Denisov IG, Sligar SG. Activation of molecular oxygen in cytochromes P450. In: Ortiz de Montellano PR, editor. Cytochrome P450, Structure, Mechanism, and Biochemistry. 4th ed. Cham: Springer (2015). p. 69109. doi: 10.1007/978-3-319-12108-6_3

77. Chan HJ, Petrossian K, Chen S. Structural and functional characterization of aromatase, estrogen receptor, and their genes in endocrine-responsive and -resistant breast cancer cells. J Steroid Biochem Mol Biol. (2016) 161:7383. doi: 10.1016/j.jsbmb.2015.07.018

78. Jenzer H, Sadeghi L, Krause C, Pfister F, Stute P, Stanga Z. Behind CYP450 interaction tables - the effect of gender and age on pharmacokinetics. EJHP Sci Pract. (2012) 19:80. doi: 10.1136/ejhpharm-2012-000 $074.80 \mathrm{~b}$

79. Lovstad RA. A kinetic study on the lactoperoxidase catalyzed oxidation of estrogens. BioMetals. (2006) 19:587-92. doi: 10.1007/s10534-006-0002-3

80. Murphy MJ Jr. Molecular action and clinical relevance of aromatase inhibitors. Oncologist (1998). 3:129-30. doi: 10.1634/theoncologist.3-2-129

81. Relats C, Sadeghi L, Zbären E, Jenzer H. The role of food-drugcytochrome P450 interactions in breast cancer. Med Sci Rev. (2018) 5:2534. doi: 10.12659/MSRev.911528

82. Karibe $\mathrm{T}$, Imaoka $\mathrm{T}$, Abe $\mathrm{K}$, Ando $\mathrm{O}$. Curcumin as an in vivo selective intestinal breast cancer resistance protein inhibitor in cynomolgus monkeys. Drug Metab Dispos. (2018) 46:667-79. doi: 10.1124/dmd.117. 078931

83. Park YJ, Ahn HY, Kim HR, Chung KH, Oh SM. Ginkgo biloba extract EGb 761-mediated inhibition of aromatase for the treatment of hormone-dependent breast cancer. Food Chem Toxicol. (2016) 87:15765. doi: 10.1016/j.fct.2015.12.007

84. Simonsson $M$, Söderlind V, Henningson $M$, Hjertberg $M$, Rose C, Ingvar C, et al. Coffee prevents early events in tamoxifen-treated breast cancer patients and modulates hormone receptor status. Cancer Causes Control. (2013) 24:929-40. doi: 10.1007/s10552-0130169-1
85. Etique N, Chardard D, Chesnel A, Merlin JL, Flament S, Grillier-Vuissoz I. Ethanol stimulates proliferation, ERalpha and aromatase expression in MCF-7 human breast cancer cells. Int J Mol Med. (2004) 13:14955. doi: $10.3892 / \mathrm{ijmm} .13 .1 .149$

86. Yaginuma T, Izumi R, Yasui H, Arai T, Kawabata M. Effect of traditional herbal medicine on serum testosterone levels and its induction of regular ovulation in hyperandrogenic and oligo menorrhoic women. Acta Obst Gynaec Jpn. (1982) 34:939-44.

87. Takeuchi T, Nishi O, Okamura T, Yaginuma T. Effect of paeoniflorin, glycyrrhicin and glycyrrhetinic acid on ovarian androgen production. Am J Chinese med. (1991) 19:73-8. doi: 10.1142/S0192415X910 00119

88. Armanini D, Bonanni G, Maturello MJ, Fiore C, Sartorato P, Palermo M. Licorice consumption and serum testosteron in healthy man. Exp Clin Endocrinol Diabetes. (2003) 111:341-3. doi: 10.1055/s-2003-42724

89. Armanini D, Mattarello MJ, Fiore C, Bonanni G, Scaroni C, Sartorato P, et al. Licorice reduces serum testosterone in healthy women. Steroids. (2004) 69:763-6. doi: 10.1016/j.steroids.2004.09.005

90. Li G, Simmler C, Chen L, et al. Cytochrome P450 inhibition by three licorice species and fourteen licorice constituents. J. Pharm. Sci. (2017) 109:182-90. doi: 10.1016/j.ejps.2017.07.034

91. Adams LS, Zhang Y, Seeram NP, Heber D, Chen S. Pomegranate ellagitannin-derived compounds exhibit antiproliferative and antiaromatase activity in breast cancer cells in vitro. Cancer Prev Res. (2010) 3:10813. doi: 10.1158/1940-6207.CAPR-08-0225

92. Sanderson JT, Hordijk J, Denison MS, Springsteel MF, Nantz MH, van den Berg M. Induction and Inhibition of aromatase (CYP19) activity by natural and synthetic flavonoid compounds in H295R human adrenocortical carcinoma cells. Toxicological sciences. (2004) 82:709. doi: $10.1093 /$ toxsci/kfh 257

93. Kao YC, Zhou C, Sherman M, Laughton CA, Chen S. Molecular basis of the inhibition of human aromatase (estrogen synthetase) by flavone and isoflavone phytoestrogens: a site-directed mutagenesis study. Environ Health Perspect. (1998) 106:85-92. doi: 10.1289/ehp.9810685

94. Orellana BM, Guajardo TV. Actividad del citocromo P450 y su alteración en diversas patologías. Revista Médica De Chile. (2004) 132:85-94. doi: 10.4067/S0034-98872004000100014

95. Meskin MS, Bidlack WR, Randolph RK editors. Phytochemicals: Nutrient-Gene Interactions. Florida City: CRC Press (2006). doi: 10.1201/9781420005905

96. Tanaka J, Nakamura S, Tsurama K, Shiazawa M, Shimoda H, Hara H. Purple rice (Oryza sativa L.) extract and its constituents inhibit VEGF-induced angiogenesis. Phytother Res. (2012) 26:214-22. doi: 10.1002/ptr.3533

97. Viry E, Anwar A, Kirsch G, Jacob C, Diederich M, Bagrel D. Antiproliferative effect of natural tetrasulfides in human breast cancer cells is mediated through the inhibition of the cell division cycle 25 phosphatases. Int $J$ Oncol. (2011) 38:1103-11. doi: 10.3892/ijo.2011.913

98. Park KR, Nam D, Yun HM, Lee SG, Jang HH, Sethi G, Cho SK, Ahn KS. B-caryophyllene oxide inhibits growth and induces apoptosis through the suppression of PIK3/AKT/mTOR/S6K1 pathways and ROS-mediated MAPKs activation. Cancer Lett. (2011). 312:178-88. doi: 10.1016/j.canlet.2011.08.001

99. Attoub S, Hassa AH, Vanhoecke B, Iratni R, Takahashi T, Gaben AM, et al. Inhibition of cell survival, invasion, tumor growth and histone deacetylase activity by the dietary flavonoid luteolin in human epithelioid cancer cells. Eur J Pharmacol. (2011) 651:18-25. doi: 10.1016/j.ejphar.2010.10.063

100. Meng J, Li Y, Camarillo C, Yao Y, Zhang Y, Xu C, et al. (2014). The anti-tumor histone deacetylase inhibitor SAHA and the natural flavonoid curcumin exhibit synergistic neuroprotection against amyloid-beta toxicity. PLoS ONE 9:e85570. doi: 10.1371/journal.pone.0085570

101. Berger A, Venturellia S, Kallnischkies MK, Böcker A, Busch $C$, Weiland $T$, et al. Kaempferol, a new nutrition-derived paninhibitor of human histone deacetylases. J Nutr Biochem. (2013) 24:977-85. doi: 10.1016/j.jnutbio.2012.07.001

102. Willyard C. Heritability: the family roots of obesity. Nature. (2014) 508:S5860. doi: 10.1038/508S58a

103. Heijmans BT, Tobi EW, Stein AD, Putter H, Blauw GJ, Susser ES, et al. Persistent epigenetic differences associated with prenatal exposure 
to famine in humans. Proc. Natl. Acad. Sci. USA. (2008) 105:170469. doi: 10.1073/pnas.0806560105

104. Tobi EW, Lumey LH, Talens RP, Kremer D, Putter H, Stein AD, et al. DNA methylation differences after exposure to prenatal famine are common and timing- and sex-specific. Hum Mol Genet. (2009) 18:404653. doi: 10.1093/hmg/ddp353

105. Burns J, Yokota T, Ashihara H, Lean MEJ, Crozier A. Plant foods and herbal sources of resveratrol. J Agric Food Chem. (2002) 50:333740. doi: 10.1021/jf0112973

106. Wu C, Yang J, Wang F, Wang X. Resveratrol: botanical origin, pharmacological activity and applications. Chin J Nat Med. (2013) 11:115. doi: 10.1016/S1875-5364(13)60001-1

107. Sebastia N, Montoro A, Manes J, Soriano J. A preliminary study of presence of resveratrol in skins and pulps of European and Japanese plum cultivars. $J$ Sci Food Agric. (2012) 92:3091-4. doi: 10.1002/jsfa.5759

108. Nemcova L, Zima J, Barek J, Janovska D. Determination of resveratrol in grains, hulls and leaves of common and tartary buckwheat by HPLC with electrochemical detection at carbon paste electrode. Food Chemistry. (2011) 126:374-8. doi: 10.1016/j.foodchem.2010.10.108

109. Jerkovic V, Collin S. Occurrence of resveratrol and piceid in American and European hop cones. J Agric Food Chem. (2007) 55:8754-8. doi: 10.1021/jf071792k

110. Sanders T, McMichael RW, Hendrix KW. Occurrence of resveratrol in edible peanuts. J Agric Food Chem. (2000) 48:1243-6. doi: 10.1021/jf990737b

111. Wang SY, Chen C, Wang CY, Chen P. Resveratrol content in strawberry fruit is affected by preharvest conditions. J Agric Food Chem. (2007) 55:826974. doi: $10.1021 /$ jf071749x

112. Win M, Abdul-Hamid A, Baharin BS, Anwar F, Saari N. Effects of roasting on phenolics composition and antioxidant activity of peanut kernel flour. Eur Food Res Technol. (2011) 233:599-608. doi: 10.1007/s00217-011-1544-3

113. Lyons MM, Yu C, Toma RB, Cho SY, Reiboldt W, Lee J, et al. Resveratrol in raw and baked blueberries and bilberries. J Agric Food Chem. (2003) 51:5867-70. doi: 10.1021/jf034150f

114. Shemin D. The biosynthesis of porphyrins. In: Conference on Hemoglobin: 2-3 May 1957. Washington: DC: National Academies Press (US); National
Academy of Sciences (US) and National Research Council (US); Division of Medical Sciences (1958). Available online at: https://www.ncbi.nlm.nih.gov/ books/NBK224288/ (accessed February 28, 2019).

115. Sun T, Oh WK, Jacobus S, Regan M, Pomerantz M, Freedman ML, et al. The impact of common genetic variations in genes of the sex hormone metabolic pathways on steroid hormone levels and prostate cancer aggressiveness. Cancer Prev Res. (2011) 4:2044-50. doi: 10.1158/1940-6207.CAPR-11-0283

116. Hemminki K, Försti A, Bermejo JL. The 'common diseasecommon variant' hypothesis and familial risks. PLoS ONE. (2008) 3:e2504. doi: 10.1371/journal.pone.0002504

117. Manolio TA, Collins FS, Cox NJ, Goldstein DB, Hindorff LA, Hunter DJ, et al. Finding the missing heritability of complex diseases. Nature. (2009) 461:747-53. doi: 10.1038/nature08494

118. Martin AR, Kanai M, Kamatani Y, Okada Y, Neale BM, Daly MJ. Clinical use of current polygenic risk scores may exacerbate health disparities. Nat Genet. (2019) 51:441261. doi: 10.1038/s41588-0190379-x

119. Sullivan PF. The psychiatric GWAS consortium: big science comes to psychiatry. Neuron. (2010) 68:182-6. doi: 10.1016/j.neuron.2010. 10.003

120. Stanford Health Care. Stanford South Asian Translational Heart Initiative. https://stanfordhealthcare.org/medical-clinics/stanford-south-asiantranslational-heart-initiative.html (accessed April 30, 2019).

Conflict of Interest: The authors declare that the research was conducted in the absence of any commercial or financial relationships that could be construed as a potential conflict of interest.

Copyright (C) 2020 Jenzer and Sadeghi-Reeves. This is an open-access article distributed under the terms of the Creative Commons Attribution License (CC BY). The use, distribution or reproduction in other forums is permitted, provided the original author(s) and the copyright owner(s) are credited and that the original publication in this journal is cited, in accordance with accepted academic practice. No use, distribution or reproduction is permitted which does not comply with these terms. 